\title{
1. The role of private international law in the protection of art and cultural objects
}

\section{INTRODUCTION}

Art and cultural objects form separate classes of objects that speak to the human condition and that mirror the life conditions of individuals and communities. Humans tend to develop a deep sense of personal attachment to antiquities.

Art is notoriously difficult to define. It has been called an 'unimaginable resource' that can, in the drive to make everything visible, extinguish sight. ${ }^{1}$ It is nonetheless evident that art bestows gifts on many. The free and joyous activity that produces art can transform experience or alleviate suffering. It can enhance direct, immediate experience, push us to see, as if for the first time. ${ }^{2}$ Its effects may provide a bulwark against an oppressive social order ${ }^{3}$ or prompt us to seek co-operation. ${ }^{4}$

Art is particularly hard to define for purposes of interpreting relevant legislation such as export regulations and procedures. ${ }^{5}$ The architectural heritage may qualify to be treated as having more than commercial value, for instance, ${ }^{6}$ but when is a sculpture an ornament, a fixture, a fitting or an integral part of an architectural structure? 65.

1 J Baudrillard, The Conspiracy of Art (tr A Hodges) (The MIT Press 2005)

2 LB Gilkey, 'Can Art Fill the Vacuum' in D Apostolos-Cappadona (ed), Art, Creativity and the Sacred (Continuum 1996) 187, 188-89.

3 TW Adorno, Minima Moralia: Reflections from Damaged Life (tr by D Redmond 2005, Suhrkamp Verlag 1951) aphorism 143.

4 L Tolstoy, What Is Art? (tr A Maude 1898, The Brotherhood Publishing Company) 210.

5 E.g. Canova's sculpture 'The Three Graces', which is ensconced in a domed temple at Woburn Abbey (1814-1817). See SE Bush, 'The Protection of British Heritage: Woburn Abbey and The Three Graces' (1996) 5 IJCP 269.

6 Kozacioglu v Turkey [GC] (Application no 2334/03), 19 February 2009, 72; Preamble $\S 18$ of the 2005 UNESCO Convention on the Protection and 
'Cultural objects' embody archaeological, ethnological or historical information about the creative process and the identity of the group responsible for its production. A cultural object may form part of the functions of the life process of society, ${ }^{7}$ and produce cultural identity at the same time. Identity may have a local or sub-state group focus, ${ }^{8}$ and is not reserved for the nation state (which can be defined in several different ways). ${ }^{9}$

Cultural objects are defined by the significance they have for states and for sub-national groups. ${ }^{10}$ Particular value systems ascribe subjective importance to the specific interest that attaches to cultural objects. The special status of these objects is linked to the human need for roots. ${ }^{11}$ What a community or group recognises as part of its identity, and as representative of its symbolic continuity beyond its contingent existence, helps to identify that group. The significance of an object is not determined by the recognition achieved beyond that state or group.

Cultural objects tend to operate as repositories of knowledge that endure from generation to generation. ${ }^{12}$ Consumer goods may attain

Promotion of the Diversity of Cultural Expressions, 20 October 2005, CLT-2005/ Convention Diversite-Cult Rev <http://www.unesco.org/fileadmin/MULTI MEDIA/HQ/CLT/CLT/pdf/conventiontext_og_civilsociety_en.pdf> accessed 25 February 2014; entry into force in 2007.

7 GH Hartman, The Fateful Question of Culture (Columbia University Press 1997) 56, in response to H Arendt, Between Past and Present (The Viking Press 1961) 208.

8 K Last, 'Cultural Pluralism and the Return of Cultural Heritage' in S Tierney (ed), Accommodating Cultural Diversity (Ashgate 2007) 124-25.

9 In practice, it is up to national courts to decide whether an entity falls under the definition of a state in a particular situation. See N van Woudenberg, State Immunity and Cultural Objects on Loan (Martinus Nijhoff 2012) 20.

10 Meaning adopted in the 1995 UNIDROIT Convention on Stolen or Illegally Exported Cultural Objects, 24 June 1995, 34 ILM 1330; entry into force 1 July 1998, <http://www.unidroit.org/instruments/cultural-property/1995convention> accessed 24 February 2014.

11 For more, see S Weil, The Need for Roots (Routledge 2002) 41, 51.

12 For more, see P Gerstenblith, 'Identity and Cultural Property: The Protection of Cultural Property in the United States' (1995) 75 Boston University Law Review 559, 569-70; F Francioni, 'Culture, Heritage and Human Rights: An Introduction' in F Francioni and M Scheinin (eds), Cultural Human Rights (Martinus Nijhoff 2008) 1, 6; F Francioni, 'Beyond State Sovereignty: The Protection of Cultural Heritage as a Shared Interest of Humanity' [2004] Michigan JIL 1209, 1221. 
iconic status, embodying cultural identity. ${ }^{13}$ Education can further both the significance and the level of appreciation shown for these objects.

The 'culture' in 'cultural objects' can be understood as the distinctive spiritual, material, intellectual and emotional features of society or groups - a force that co-determines what is created - such as art - and what is assimilated - lifestyle, ways of living together, value systems, traditions and beliefs. ${ }^{14}$ The universality and dynamic thrust of the concept of 'culture' challenges us, for it prompts us to develop '... all sides of our humanity ... and ... all parts of our society'. ${ }^{15}$ The implication of the coexistence of different cultures, ${ }^{16}$ which requires a dialogue of parity among the cultures of the world, ${ }^{17}$ is inescapable. Because culture makes 'identity' conceivable but also gives expression to our humanity, it fosters more than mere belonging. In fact, its identityproviding role is rather less important than its capacity to foster human connection and solidarity despite difference. ${ }^{18}$ An assumption that the drive for identity ends in political harmony (or that political harmony is attainable at all) is false. Such a drive can undermine the very co-operation that cultural objects inspire, justifying obliteration of the identity of the 'other'. A dialogue of parity is only possible if diverse cultural values are accommodated; if value does not depend on the role which they are assigned to fulfill and where preference plays no part.

The technique of legal definition differs across legal systems. In practice, there are different domestic systems of definition in relation to cultural objects. An enumeration system makes specific mention of each type of item that it proposes to protect (e.g. the Netherlands). A

13 E.g. the 1960s British Mini, or the 1950s German Volkswagen.

14 Preamble to UNESCO's Universal Declaration on Cultural Diversity, Paris, 2 November 2001 (2002) 47 ILM 57.

15 M Arnold, Culture and Anarchy (Cambridge 1935) 11.

16 Objectives of the UNESCO Convention on the Protection and Promotion of the Diversity of Cultural Expressions (n 6); Art 15 of the International Covenant on Economic, Social and Cultural Rights, 16 December 1966, 993 UNTS 3; UN Committee on Economic, Social and Cultural Rights, General Comment 21: Right of Everyone to Take Part in Cultural Life 42 UN Doc E/C. 12/GC21 (21 December 2009); and the cultural heritage agendas of UNESCO and UNIDROIT.

17 R Pannikar, Cultural Disarmament: The Way to Peace (John Knox Press 1995) 34.

18 A Appiah, 'Cosmopolitanism: Ethics in a World of Strangers' in LV Prott (ed.) Witnesses to History: A Compendium of Documents and Writings on the Return of Cultural Objects (Unesco Publications 2009) 95, 109; Pannikar (n 17) 34. 
categorisation system provides a very general description of what is to be protected (e.g. Germany). A classification system extends protection to a specific object only when a specific administrative decision is made to that effect (e.g. the UK). Various combinations of these systems are in operation across the world. ${ }^{19}$ Italy combines categorisation with classification. ${ }^{20}$ Turkey combines extensive listing in respect of some property but categorises other kinds of property. ${ }^{21}$ Canada combines an inventorybased approach with administrative orders. ${ }^{22}$

Some states protect classes of artefacts that are unique to their national histories and that have considerable historic and artistic merit. They can be 'the centerpieces of active cultures and religions, illustrations of the changing patterns of aesthetics, anthropological records of previous societies, beautiful and desirable items which confer prestige on their owners, or commodities in the international art market'. ${ }^{23}$ While the objects that states feel constrained to protect are frequently old, the tendency in the majority of national laws to define protected categories of objects by age means that the artistic or historical significance of modern art remains unaccounted for.

With the challenges and the differences in the technique of definition in mind, it is understandable that an objective definition of cultural objects is difficult to provide in abstracto. ${ }^{24}$ In no more than a very general sense, therefore, the term 'cultural objects' can be understood to mean the physical remains of the past, man-made objects that are of

19 For more, see LV Prott and PJ O'Keefe, Law and the Cultural Heritage Vol. 3 Movement (Professional Books 1984-1989) 26-30. National laws are available from the UNESCO Database of National Cultural Heritage Laws.

20 Among others Protection of Items of Artistic or Historical Interest, Law No. 1089 of 1939; Consolidated Act for Cultural Heritage and the Environment, Law Decree No. 490 of 25 October 1999; Code of Cultural Property of 2004.

21 Among others Conservation of Cultural and Natural Property Law No. 2863, Official Gazette 23/07/1983 no 18113; Regulation on the Classification, Registration and Admission to Museums of Movable Cultural and Natural Assets Requiring Preservation of 2009.

22 Among others Cultural Property Export and Import Act of 1985, Consolidated Statutes of Canada, Chapter c 51 RSC 1985; Cultural Property Export Control Regulation; Order Establishing a Canadian Export Control List.

23 LJ Borodkin, 'The Economics of Antiquities Looting and a Proposed Legal Alternative' (1995) Columbia Law Review 377.

24 UNIDROIT Secretariat, Explanatory Report to the 1995 Unidroit Convention on Stolen or Illegally Exported Cultural Objects (2001) 3 Uniform Law Review 476, 496. 
archaeological, historical, pre-historical, artistic, scientific, literary or technical interest.

\section{CULTURAL HERITAGE LAW: NO STANDARD DEFINITION OF 'CULTURAL HERITAGE' POSSIBLE}

Cultural heritage law is a conceptual framework in the form of a legal category that reflects trends and developments of international cultural law and its interactions with other fields of law. ${ }^{25}$ It emerged as a new, separate category of law in $1990 .^{26}$ The cultural component of 'cultural heritage' is capable of carrying a composite meaning that embraces the tangible results of cultural activities, the processes of artistic and scientific creativity, and the ways of life of groups and communities. ${ }^{27}$ As such, it conveys a meaning that is wider than 'cultural objects'. The term $^{28}$ is sufficiently wide to capture other markers of national or group identity, such as intangibles, language, traditional cultural expressions, folklore, genetic resources and intellectual property. In other words, the learning processes, traditions, knowledge and skills which were inherited from past generations, and which provide the identity that communities desire to transmit to future generations are included. ${ }^{29}$

This study considers the national and international law that makes cultural heritage law in the narrower respect of the tangible results of creative endeavour. These are corporeal and moveable objects that deserve to be maintained, cherished, preserved and bestowed. ${ }^{30}$

25 V Vadi, Cultural Heritage in International Investment Law and Arbitration (CUP 2014) 23.

26 LV Prott, 'Problems of Private International Law for the Protection of the Cultural Heritage' V Recueil des Cours (The Hague 1989) 214ff; A Chechi, The Settlement of International Cultural Heritage Disputes: Towards a Lex Culturalis? (unpublished $\mathrm{PhD}$ Thesis EUI 2011) 247ff supports a new taxonomy.

27 Vadi (n 25) 19.

28 For more on terminology, see Vadi (n 25) 24-29. The term 'cultural heritage' was officially adopted by the United Nations Educational, Scientific and Cultural Organization (UNESCO) in the 1972 Convention for Protection of the World Cultural and Natural Heritage <http://whc.unesco.org/en/convention text/> accessed on 30 June 2014. It includes 'cultural property', and its use is in line with current treaty practice.

29 Francioni (n 12) 6; Vadi (n 25) 19.

30 LV Prott and PJ O'Keefe, Law and the Cultural Heritage Vol 1 (Professional Books 1984-1989) 7. 
The challenges posed by cultural heritage law highlight the importance of the scope of the definition of cultural heritage (to the extent that legal norms can define the notion without reference to other disciplines). ${ }^{31}$ It is important to establish control of the process of definition, for purposes of ensuring that a particular object is covered by the law concerned. Legal definitions necessarily reflect the cultural values of the drafter and the social constructions of categories of material culture. Minority cultures may be sidelined when the significance which the possessor ascribes to an object is different from the claimant's perspective. ${ }^{32}$ It could mean the difference between protection and the failure to protect.

\section{PROTECTION AND THE FAILURE TO PROTECT}

\subsection{Cultural Priorities in the US, the EU and the UK}

National laws set their own cultural priorities and offer only one definition among many possibilities. They cannot supply a standard definition. What a single domestic legal system can accomplish when offering diverse definitions is to limit overlaps between different sets of rules for different types of cultural property. US law offers a fine example of a legal system that relies on various treaties, laws and policies to identify particular objects of material culture that are worthy of legal protection. ${ }^{33}$ Cultural property stolen from a museum or a religious or secular public monument or similar institution, which is documented as appertaining to the inventory of that institution, represents a category for

31 L Casini, "'Italian Hours": The Globalization of Cultural Property Law" (Jean Monnet Working Paper 10, September 2010) <http://centers.law.nyu.edu/ jeanmonnet/papers/10/101101.pdf $>$ accessed 24 February 2014.

32 Last (n 8) 124, 126.

33 US federal statutes define designated archaeological material (Cultural Property Implementation Act (CCPIA), Pub L 97-446, Title III, 96 Stat. 2350 (1983), 19 US Code 2601-2613); archaeological resources (Ancient Monuments and Archaeological Areas Act 1979); cultural items (Native American Graves Protection and Repatriation Act (NAGPRA), 25 US Code 3001-3013 (2000)); historical property and resources (National Historic Preservation Act (NHPA), 16 US Code 470aa-470mm (2000)); as well as commemorative works and objects of cultural heritage, 18 US Code Appx $\S 2 \mathrm{~B}$ 1.5. P Gerstenblith, 'Recent Developments in the Legal Protection of Cultural Heritage' in N Brodie, MM Kersel, C Luke and K Walker Tubb (eds), Archaeology, Cultural Heritage and the Antiquities Trade (University Press of Florida 2006) 68, 75. 
purposes of the implementation of Article 7(b) of the UNESCO Convention on the Means of Prohibiting and Preventing the Illicit Import, Export and Transfer of Ownership of Cultural Property. ${ }^{34}$ Endangered archaeological and ethnological materials designated by the President subject to determinations by the Cultural Property Advisory Committee ${ }^{35}$ form an independent category for purposes of implementing Article 9 of the UNESCO Convention. Bilateral treaties set out importation restrictions, provisions with regard to seizure if they have been violated, and provisions for the return of specific archaeological and ethnographic materials to their territory (whether state or sub-state). ${ }^{36}$

The EU concept 'cultural treasures' 37 signifies protective regimes that derogate from free movement in the internal market. ${ }^{38}$ The internal market consists of a space without internal frontiers in which persons, goods, services and capital move freely as the Treaty on European Union envisages, but the EU allows exceptions for restrictions imposed for the protection of national treasures possessing artistic, historic or archaeological importance.

3414 November 1970, 823 UNTS 231; 10 ILM 289.

35 M Papa-Sokal, 'The US Legal Response to the Protection of the World Cultural Heritage' in N Brodie, MM Kersel, C Luke and K Walker Tubb (eds), Archaeology, Cultural Heritage and the Antiquities Trade (University Press of Florida 2006) 36, 44-45.

36 A list of states is available at <http://www.unesco.org/eri/la/convention. asp?KO=13039\&language=E $>$ accessed 25 February 2014.

37 The definition ought to be uniform but the nomenclature differs in the context of export controls (e.g. 'Kulturgut' in German; 'patrimonio nazionale' in Italian). The definition is considerably wider in Greece, Italy, Cyprus and Spain, than in other EU Member States. The ECJ did not define the concept when it considered the compatibility of a governmental measure of protection of cultural property with free trade requirements in Case 7/68 EC Commission v Italy [1969] CMLR 1 (ECJ) and Case 48/71 EC Commission v Italy [1972] ECR 527.

38 Member States define their own national treasures. The definition in Directive 93/7/EEC has been adapted by Directive 2014/60/EU for the future. See Council Directive 93/7/EEC of 15 March 1993 on the Return of Cultural Objects Unlawfully Removed from the Territory of Member States Council Directive (EEC) 93/7 of 15 March 1993 on the return of cultural objects unlawfully removed from the territory of a member state OJ L 74/74, 27.3.93 (with amendments in 1997 and 2001); Directive 2014/60/EU of the European Parliament and of the Council of 15 May 2014 on the Return of Cultural Objects Unlawfully Removed from the Territory of a Member State and amending Regulation (EU) No 1024/2012 (Recast) OJ EU L159/1, 28.5.2014. 
The commercial value of cultural objects may appreciate with time. ${ }^{39}$ The UK confined its use of the term 'cultural property' to the items referred to in instruments of EU law for purposes of the application of the 1970 UNESCO Convention. ${ }^{40}$ Whereas age and minimum financial value of certain types of objects used to function as criteria in EU law, this approach has now been revised. The scope of application of the new Directive 2014/60/EU ${ }^{41}$ extends to cultural objects that are classified or defined by the Member States as a cultural treasure. Directive 2014/ 60/EU now acknowledges that it should be possible for Member States to return cultural objects other than those classified or defined as national treasures provided that they respect the relevant provisions of the TFEU, as well as cultural objects unlawfully removed before 1 January 1993.42

Any special law would define the field of its application. In instances where claims for return are not based on special laws or international instruments, the question of classification may well remain unanswered. ${ }^{43}$ In England and Scotland, the concepts of treasure and buried ownerless property are defined in common law and legislation, but no special definition exists for cultural objects otherwise. ${ }^{44}$ The 2003 Cultural Objects (Offences) Act does not attempt to add national definition, and nor do the Waverley Criteria, which are the Export Regulations that prevent cultural objects of monetary value exceeding the limits of the Open General Export Licence from leaving the country if a matching

39 B Demarsin, 'The Third Time Is Not Always a Charm: The Troublesome Legacy of a Dutch Art Dealer: The Limitation and Act of State Defences in Looted Art Cases' (2010) 28 Cardozo Art and Entertainment Law Journal 255, 257; A Hawkins, 'A Tale of Two Innocents: Creating an Equitable Balance between the Rights of Former Owners and Good Faith Purchasers of Stolen Art' (1995) 64 Fordham Law Review 49, 50.

40 Regulation 116/2009 of 18 December 2008, OJ L 39/1 (2009); Council Directive (EEC) 93/7 of 15 March 1993 (n 38).

41 Directive 2014/60/EU (n 38).

42 Recital 10.

43 B Schönenberger, The Restitution of Cultural Assets (Eleven International Publishing 2009) 42.

44 Return of Cultural Objects Regulations 1994, SI No 501 of 1994 as amended by SI No 1719 of 1997; SI 3972 of 2001. The implications of introducing limitation rules for cultural objects have been considered. Scottish Law Commission Discussion Paper on Prescription and Title to Moveable Property No 144 (Edinburgh 2010) Chapter 4; DL Carey Miller, DW Meyers and AL Cowe, 'Restitution of Art and Cultural Objects: A Re-Assessment of the Role of Limitation' [2001] Art Antiquity and Law 1, 11. 
offer can be raised domestically. ${ }^{45}$ The decision to grant a licence rests with the Reviewing Committee on the Export of Works of Art. ${ }^{46}$ Export of works of art older than 50 years is governed by the Import, Export and Customs Powers (Defence) Act of 1939 and requires a licence. The absence of a register for corporeal moveables is unlike the position in Germany, where registered cultural objects qualify for protection against removal. ${ }^{47}$

Demarcation difficulties increase the risk of litigation for innocent dealers and traders in the legitimate art market. ${ }^{48} \mathrm{~A}$ claim in respect of a cultural treasure based on an international instrument or an EC Directive would be guided by the categories enumerated therein. It is up to national courts to recognise these categories in international cases and to decide whether a sufficient interest has been established for purposes of a claim.

\subsection{Different Situations Call for Protection}

Protection by the state or an institution of the state could be called for in a number of different situations. ${ }^{49}$ A state may seek to protect the rights of an owner of the object, e.g. to enable deprived owners to enforce their rights by recovering stolen objects. A state may seek to ensure physical continuance of the object, e.g. by preventing its destruction or deterioration, even while in the hands of a private owner, because of the heritage value of the object. In the capacity of custodian of the cultural heritage for the community it derives from, a state may seek to protect access to an object by requiring its display and preventing its exportation.

The underground market is a factor in the movement of art and cultural objects. The tentacles of the illicit trade reach into the cultural life of communities in developed and developing economies alike. Cultural

45 Waverley Committee Report, RA Butler 6 September 1952, Report of a Committee appointed by the Chancellor of the Exchequer HMSO 1952.

46 Export permission was refused in respect of 'The Three Graces' by Canova in 1994 (n 5), and export of 'Portrait of Everhard Jabach and family' by Charles Le Brun (1619-1690) was barred until 6 May 2014. <https:// www.gov.uk/government/news/painting-deemed-national-treasure-may-leave-uk> accessed 11 March 2014.

47 European Commission, Study Report on Preventing and Fighting Illicit Trafficking in Cultural Goods in the European Union, 10 October 2011, 190-94, 248-249<http://ec.europa.eu/home-affairs/doc_centre/crime/docs/Report\%20 Trafficking\%20in\%20cultural\%20goods\%20EN.pdf> 194 accessed 12 March 2014.

48 Carey Miller et al. (n 44) 10-11.

49 Prott (n 26) 235. 
trafficking displaces art and cultural objects. Traffickers may try to evade claims by relocating the object, and their success in doing this may erode respect for the law. Protection may require return of cultural objects that have been retained unlawfully, ${ }^{50}$ or of parts of cultural sites that had been removed during armed conflict. ${ }^{51}$

The unethical, immoral trade tends to be illegal in the source state, ${ }^{52}$ but this is not necessarily the case in every market state. ${ }^{53}$

\subsection{Failing to Protect}

States may fail to protect cultural objects or to regulate trafficking because they benefit from the illegal or illicit trade. Ambiguity in a particular state policy can mean that cultural objects that were taken abroad without a permit are sought out and claimed, while objects with historical and archaeological significance to certain ethnic groups are left unguarded. ${ }^{54}$ States have the capacity for white-collar crime and state control of their own citizens and museums. ${ }^{55}$ States may also assume a deliberate stance based on a national policy to confiscate cultural property belonging to particular segments of society. Turning against their own citizens and museums, they may use their strength to enforce private property rights to expropriate art. Expropriation can be achieved,

50 E.g. cultural objects excavated contrary to the law or excavated legally but unlawfully retained; see Clause 4 of the State Ownership of Undiscovered Cultural Objects. Text supplied in M Frigo, 'Model Provisions on State Ownership of Undiscovered Cultural Objects - Introduction' [2011] Uniform Law Review 1044.

51 E.g. Case Concerning the Temple of Preha Vihear (Cambodia and Thailand), judgment of 15 June 1962, Merits, ICJ Reports (1962) 6ff.

52 Source states are rich in cultural materials for which there is a world market, but local demand for cultural materials keep the prices low. Examples include Mexico, India and Guatemala.

53 Market states are economically strong and the demand for cultural objects is high. Examples include the US and the UK.

54 AJG Tijhuis, Transnational Crime and the Interface between Legal and Illegal Actors: The Case of the Illicit Art and Antiquities Trade (Wolf Legal Publishers 2006) 161; A Efrat, 'Getting Governments to Co-operate against Looting: Insights from the American and British Experience' <http://portal. idc.ac.il/facultypublication.publication?PublicationID=2874\&FacultyUserName= YXNpZg==> accessed 24 February 2014, comparing the position of the US and Britain in respect of the UNESCO Convention.

55 E.g. Kommerziele Koordinierung (KoKo) combined state control, state intelligence and white collar crime in East Germany in the 1970s and 1980s, and benefited from art crime among other things. Tijhuis (n 54) 160, 172. 
through military or other means, without any existing or even alleged legitimate purpose. It is also possible to delay and obstruct dispute settlement by grossly unfair and unethical methods. Sheer indifference in respect of physical preservation and evasion of return procedure can also do much harm. The indifference to the cultural heritage of those under their control meant that the occupying powers remained blatantly inactive when the antiquities scattered along the 'Old Silk Road' became coveted prizes in the international race for ancient Buddhist treasures. As Confucians who despised Buddhism, the prejudice of the Chinese officials allowed iconoclastic Moslems to proceed unchecked to damage frescoes, sites and treasures from Chinese Turkestan. ${ }^{56}$ The tide has turned. Chinese authorities have been building global solidarity by means of international scientific involvement and participation in respect of, for instance, part of the Buddhist treasures that lie preserved in the time capsule of painted sculptures, murals, wooden architecture and relics of the Silk Road at the Mogao caves at Dunhuang. ${ }^{57}$

It is widely conceded that cultural objects deserve special treatment, and yet in practice, general commercial law rules are readily given extended application. The commercial imperative is discussed next.

\section{COMMERCIAL IMPERATIVE}

\subsection{Trading on the Art Market}

Today's art market is a multibillion dollar industry. ${ }^{58}$ It consists in a 'myriad, often over-lapping, subspecialties that may be limited by region

56 P Hopkirk, Foreign Devils on the Silk Road: The Search for the Lost Cities and Treasures of Chinese Central Asia (OUP 1980) 24, 31. For a photographic record of the Nepalese tragedy involving the looting of Buddha statues during the 1980s, see J Schick, The Gods Are Leaving the Country (Orchid Press 1999).

57 Its 735 caves are cut into a cliff located $25 \mathrm{~km}$ southeast of Dunhuang. Cave construction began in $366 \mathrm{CE}$ and continued for another thousand years. The National Library of China based in Beijing, national libraries of the UK and France, the Russian Academy of Sciences and the Mellon Foundation in the US are all in collaboration with the Dunhuang Academy on the 'Digital Dunhuang' Project. For more, see <http://www.expo2010.cn/expo/english/eu/nc/ct/user object1ai12652.html> accessed 23 July 2014.

58 D Chappell and K Polk, 'Unravelling the "Cordata": Just How Organized Is the International Traffic in Cultural Objects?' in S Manacorda and D Chappell (eds), Crime in the Art and Antiquities World (Springer 2011) 99, 101. 
(e.g. Asian or North-American), by date (mediaeval, contemporary), by medium (paper, bronze) or by form (paintings, furniture) ... and archaeological and ethnographic materials ... [which] their countries of origin consider cultural heritage ...' ${ }^{59}$ The sale of works of art in the arena of the art market is an important commercial activity in many states, although a relatively small number of dealers are involved and there are significantly fewer works compared to the number of fungible goods in international trade. ${ }^{60}$ The art trade makes an economic and cultural contribution which governments cannot ignore. ${ }^{61}$

The trade in art is also an intercontinental, transnational trade. The art trade readily crosses national borders, and has done so ever since the recorded development of the art market. ${ }^{62}$ The 1680s saw the repeal of a law that banned the importation of paintings into England. There was then a great influx of paintings from the Lowlands, where significantly large numbers of people invested in pictures and paintings. ${ }^{63}$ Today, London is at the global centre of cultural trade in European, South Asian and Middle Eastern art. ${ }^{64}$ Most years, New York has the largest sales turnover in the world. This market focuses on Canadian, North American and South American art. Beijing claimed first place in 2012,65 but it generally functions as a secondary national centre for the Asian trade in the primary location of Hong Kong. Emerging markets such as Iran, India and China have national markets that serve national developmental aims. ${ }^{66} \mathrm{~A}$ selfsustaining national market was established in China in the 1990s, ${ }^{67}$ but today, China has one of the fastest-growing art and antiquities auction sectors in the world. ${ }^{68}$ While domestic business will dominate the Chinese

59 CC Coggins, 'A Licit International Traffic in Ancient Art: Let There Be Light' (1995) 4 IJCP 61, 65-66.

60 Gerstenblith (n 12) 569; JH Merryman, 'Cultural Property, International

Trade and Human Rights' (2001) 19 Cardozo Arts and Entertainment 51, 52.

61 Efrat (n 54).

62 Schönenberger (n 43) 27; P Watson, From Manet to Manhattan (Random House UK 1992) 46.

63 Watson (n 62) 49.

64 I Robertson, A New Art from Emerging Markets (Lund Humphries 2011) 78.

65 S Blanc, 'New Fronts Open in Chinese Art Market as Records Fall' API (11 October 2013).

66 Robertson (n 64) 14.

67 Robertson (n 64) 76.

68 JL Graham, 'Art Exchange: How the International Art Market Lacks a Clear Regulatory Framework' in V Vadi and HEGS Schneider (eds), Art, Cultural Heritage and the Market: Legal and Ethical Issues (Springer 2014) 323. 
art market for the foreseeable future, China has also opened its doors more widely to Sotheby's and Christie's. Sotheby's boasts a joint venture with a state-run company, and Christie's won a licence in 2013 to become the first international auction house to operate independently in China.

\subsection{A Globalised Capitalist Art Market}

The commodities trade in liberal capitalist societies are characterised by the commercial imperative that, in principle, the bona fide purchaser of a moveable thing should get a good title regardless of provenance. It is a matter of the market context facilitating easy title in order to promote commerce in many parts of the world. ${ }^{69}$ Ordinary business norms may be appropriate to the transfer and exchange of many forms of art, but the protection of museum pieces, pieces obtained on the black market, and some forms of indigenous cultural heritage require different rules and approaches. $^{70}$

Capitalism demands a continued readjustment of the self and what the self produces in response to the market. ${ }^{71}$ This feature is most prominent at art fairs, where art is a globally traded commodity and the art market is largely unfettered. Different considerations are supposed to come into play where cultural heritage is concerned, but mechanisms that keep unbridled self-interest in check are absent in capitalist markets. The commercial imperative is insensitive to the importance of transmission of culture to current and future generations; or to the need for controlling the free movement of objects whose preservation is under threat; or to the outflow of cultural materials. When alteration can improve the marketability of a piece, capitalism will not be constrained by the risk of damage. The increased competition for sales by auction houses in the emerging markets is not necessarily seen as a bad thing. Yet, what the duties of market participants are, ought to be an active concern.

69 C Roodt and D Carey Miller, 'Vitium Reale in Private Law and Private International Law' (2013) 10 TDM Special Issue 1.

70 The Western paradigm tends to confine itself to cultural rights that are 'indispensable for his dignity and the free development of his personality' by virtue of Art 22 of the United Nations Universal Declaration of Human Rights. Indigenous cultural property claims do not necessarily share this worldview. K Kuprecht and K Siehr, 'International Trade in Moveable Tangible Cultural Heritage of Indigenous Peoples: A European Perspective' in CB Graber, K Kuprecht and JC Lai (eds), International Trade in Indigenous Cultural Heritage (Edward Elgar 2012) 246, 269-70.

71 E Fromm, To Have or To Be? (Continuum 2002) 147-54; L Wilde, Global Solidarity (Edinburgh University Press 2013) 116. 
The art market can be at odds with culture. The value of certain cultural items far exceeds any possible market valuation. Other items may have no market value but may be highly deserving of national and international regulation and protection..$^{72}$ Both the most significant and the least significant of these items may constitute evidence of vanishing ways of life. In addition, notwithstanding the recognition given to cultural diversity at the international level, the major supporters of free trade and trade liberalisation construe exceptions in respect of trade in culture restrictively. Restrictions on free trade in state cultural policy are not necessarily any easier to reconcile with the commercial imperative. The World Trade Organization is not particularly responsive to indigenous interests, ${ }^{73}$ and the EU is vulnerable to the illicit trade in cultural objects. ${ }^{74}$ Even if a human rights imperative in respect of tangible heritage could enable restitution in principle, restitution is incidental at best to any finding such a body might make ${ }^{75}$ because restitution claims are not within the reach of free trade institutions.

\subsection{Constraining the Commercial Imperative}

At this point in its evolution, the art market is highly organised but largely unregulated. High prices attract and encourage roguish and criminal behaviour. The likelihood of buying cultural objects and works of art that have been stolen, looted or misappropriated in another jurisdiction, is high.

Public and private law contain provisions that contain and limit the commercial imperative and affect title issues. Public law may subject a particular object to inalienability, restricted transfer, indefeasible title, imprescriptibility or public domain rules, ${ }^{76}$ as is the case in several

72 Vadi (n 25) 20.

73 CB Graber, K Kuprecht and JC Lai (eds), 'The Trade and Development of Indigenous Cultural Heritage: Completing the Picture and a Possible Way Forward' in International Trade in Indigenous Cultural Heritage (Edward Elgar 2012) 463, 493.

74 Study Report (n 47) 100-104; A Koush, 'Fight Against the Illegal Antiquities' Traffic in the EU: Bridging the Legislative Gaps' (Bruges Political Research Papers Series 2011).

75 IF Gazzini, Cultural Property Disputes: The Role of Arbitration in Resolving Non-Contractual Disputes (Transnational Publishers Inc. 2004) 50.

76 E.g. Arts 822-828 of the Italian Civil Code of 1942; Consolidated Act for Cultural Heritage and the Environment, Law decree no 490 of 25 October 1999 (Italy); Art 174 of the Italian Code of Cultural Property of 2004 (criminal forfeiture). In general A Jakubowski, 'Return of Illicitly Trafficked Cultural 
European states. The status of inalienability is irreversible in a number of jurisdictions. ${ }^{77}$ For instance, the absence of a statutory mechanism for restitution in museum laws may mean that the museum in question is barred from initiating restitution, or that authorisation to transfer ownership or dispose of public collections will be withheld. ${ }^{78}$

Domestic public law frameworks that pay due attention to illegal export and import could catch looted objects that may otherwise be evidentially out of reach for a court. ${ }^{79}$

Private international law is called upon to assert its role in the international market for art and antiquities where most purchasers conglomerate and where prices are set. ${ }^{80}$ As a potential legal constraint in respect of the commercial imperative, it operates alongside the constraints imposed by law in other areas. It rubs shoulders with public international law, which extends protection to antiquities and cultural objects by virtue of broad international accord. It is subject to inevitable adjustments to the relative stability of private law in recognition of extreme circumstances that prevailed during the Holocaust, or the Soviet Russian 'trophy' looting post-World War II. Additionally, museum policy may disregard the title position to effect repatriation or restitution.

Much work remains to be done to systematize national law, international civil procedure and international law. Systematisation in respect of the role and effects of private international law is a relatively unchartered area, but a better understanding of this global lens can improve the level of regulation in a demanding legal context. Private

Objects Pursuant to Private International Law: Current Developments' in The Illicit Traffic of Cultural Objects in the Mediterranean (EUI Working Papers 2009) 137, 139.

77 M Cornu and M Renold, "New Developments in the Restitution of Cultural Property: Alternative Means of Dispute Resolution' (2010) 17 IJCP 1, 9-10.

78 The British Museum Act of 1963 barred the British Museum from restituting Old Master drawings in its possession (Her Majesty's AttorneyGeneral v Trustees of the British Museum [2005] EWHC 1089 (Ch)). Legislative action had to be taken.

79 S MacKenzie, 'The Market as Criminal and Criminals in the Market: Reducing Opportunities for Organised Crime in the International Antiquities Market' in S Manacorda and D Chappell (eds), Crime in the Art and Antiquities World (2011 Springer) 69, 73.

80 P Watson, 'Convicted Dealers: What We Can Learn' in N Brodie, MM Kersel, C Luke and K Walker Tubb (eds), Archaeology, Cultural Heritage and the Antiquities Trade (University Press of Florida 2006) 93, 94; Tijhuis (n 54) 176. 
international law does not determine its relation with other legal phenomena internally all by itself. Both the general theory of law and the theory of international law are well placed to contribute.

The responsibilities of participants in the art market are easily assumed to be similar to the responsibilities of participants in the commodities market. ${ }^{81}$ To counter this default position, it is necessary to consider not only the law. First of all, the effect of non-legal factors such as ideology on compliance with rules and duties can be significant. Secondly, acquisition standards and the duties of market participants do not derive only from law. A normative ideal constrains the commercial imperative and shapes the responsibilities of market participants even when legislation is absent. The normative ideal is hard to identify, given that various different ideologies are likely to compete in a global setting. Moreover, moral standards cannot be legislated into existence. The relationship between private international law and the broader ethical framework will ultimately require closer definition. Its implications for private international law is addressed under 7.6 below.

\section{THE CONTEXT IN WHICH PRIVATE INTERNATIONAL LAW MEETS CULTURAL HERITAGE LAW}

\subsection{Lodging Civil Claims}

The true owner (whether individual, museum or business) or the source state may institute a civil law suit ${ }^{82}$ to obtain restitution or return of an object that has been traded after it has been stolen, looted, excavated or smuggled into another jurisdiction.

Claims brought by foreign source states for archaeological objects they believe were removed in violation of patrimony or export laws will frequently be brought in a market state or in an intermediary (transit) jurisdiction, where the nature of the claim will be determined by private international law. There has also been a sharp increase since the Cold War has ended in the number of legal claims brought by heirs of Holocaust victims whose art works were looted or misappropriated by

81 J Ulph and I Smith, The Illicit Trade in Art and Antiquities (Hart 2012) $13-15,271$.

82 S MacKenzie, 'Illicit Deals in Cultural Objects as Crimes of the Powerful' (2011) 56 Crime Law Social Change 133, 146. 
Nazis. Either the claimant or the defendant may base their argument on private international law.

A defendant with prior knowledge of an impending claim can, prior to the court becoming seised, relocate a cultural object with a view to avoiding the establishment of jurisdiction based on the location of the object when the court is seised. ${ }^{83}$ As such, protection encompasses interim measures that are designed to prevent action to evade a return procedure after the unlawful removal of a cultural object from the territory of a particular state. ${ }^{84}$

\subsection{Art Crime and Theft}

Art crime refers to diverse acts which constitute crimes punishable by law provided they are reported and the offenders are apprehended. These acts may include art thefts and confiscations, damage and deceit, but art crime is closely linked also to the movement and outflow of cultural materials. Thus, these activities encompass clandestine excavation and illegal export ${ }^{85}$ (discussed under 6.2 below).

Art theft is frequently motivated by greed. It may provide bartering means and improve social standing.

A comparatively small number of thefts registered with the Art Loss Register (ALR) and Interpol are from museums. ${ }^{86}$ The disappearance of seven iconic pieces from the Kunsthal Museum in Rotterdam on 16 October 2012 counts among the biggest art thefts in Dutch history. The perpetrators have been convicted and sentenced, and must pay 18 million euros to the paintings' insurers, but the actual pieces have not been found. ${ }^{87}$ This past decade has seen the disappearance and dramatic recovery of, e.g., 'Boy in a Red Vest' by Cezanne, 'Poppy Field at Vetheuil' by Claude Monet and 'Blossoming Chestnut Branches' by Vincent van

83 L Gillies, 'The Conflict of Laws as a Technique of Demand Side Regulation in Claims for the Recovery of Cultural Objects' [2015] JPIL (forthcoming).

84 E.g. Art 4(5) of Council Directive (EEC) 93/7 of 15 March 1993 (n 40).

85 M Durney and B Proulx, 'Art Crime: A Brief Introduction' (2011) 56 Crime Law and Social Change 115.

86 Durney and Proulx (n 85) 121. This may have to do with assumptions made about museum security systems.

87 A Holligan, 'Dutch Art Theft Suspects Offer Paintings for Deal' $B B C$ News Europe (13 August 2013). Among them are 'Tete d'Arlequin' by Picasso, and 'Femme devant une fenetre ouverte, dite la fiancee' by Gauguin. 
Gogh. These paintings were stolen in 2008 from the private collection of EG Buhrle in Zürich and recovered before attempted sale by the thief. ${ }^{88}$

Like wealthy dwellings, museums are vulnerable to the activities of insiders such as curators. ${ }^{89}$ Designer theft ${ }^{90}$ and art-napping ${ }^{91}$ have also occurred. Virtuoso and commissioned thefts deliver art to corrupt dealers, fences or middlemen, to be sold on. ${ }^{92}$

Works of art and cultural objects can be easy to conceal and move. Even parent works that are readily identifiable and therefore unmarketable may be disguised through partitioning, which could improve the marketability of the fragments at the same time. Smaller treasures are easily transportable and concealable, setting the scene for a deceptive transnational sale. ${ }^{93}$ Once stolen, a work of art or cultural object may remain undiscovered for years, and may be hidden away deliberately, in storage sites, until it is deemed to be ripe for sale.

Most crimes never meet with criminal punishment. Deprived owners may prefer civil action. Private investigators may negotiate deals on the basis of rewards offered for recovery. The line between paying a ransom to criminals and paying a reward for information that leads to recovery is easily blurred. ${ }^{94}$

88 A Oliver and D Baker, 'Pictured: The Dramatic Moment Police Stopped Suspected Art Thief at Gunpoint and Recovered a Stolen £68.3 million Cezanne’ Mail Online (12 April 2012); A Vincent, '10 Most Wanted Missing Paintings' The Telegraph (London 25 July 2013).

89 For more on 'insider' thefts and the facilitating interface, see Tijhuis (n 54) 150-52, 157, 177-78.

90 Designer theft is the commissioned theft of selected works of art for later delivery through smuggling networks. N Palmer, 'Recovering Stolen Art' (1994) 47 Current Legal Problems 215, 216. Tijhuis (n 54) 204 highlights the absence of empirical evidence confirming that art is stolen on the order of rich collectors.

91 Art-napping is the capture of works of art for future ransom from either the owner or the insurer for the safe return of the objects (Tijhuis (n 54) 151). The National Museum in Stockholm refused to pay a ransom for three paintings by Rembrandt and Renoir in 2001 (T Grandell, 'Ransom Demand for Stolen Pictures' The Guardian (2 January 2001)) but the Tate allegedly paid to have two stolen Turners returned (G Rayner, 'Lord Myners Faced Questions over £3m Ransom for Stolen Turners' The Telegraph (28 February 2009)).

92 Tijhuis (n 54) 154.

93 G Carducci, 'The Growing Complexity of International Art Law: Conflict of Laws, Uniform Law, Mandatory Rules, UNSC Resolutions and EU Regulations' in BT Hoffman (ed) Art and Cultural Heritage: Law, Policy and Practice (CUP 2006) 68.

94 Durney and Proulx (n 85) 121; A Mostrous, 'The Murky World of the Art Detective' The Times (9 August 2014). 
Private international law assumes importance in the context of the extra-territorial effect of sales of art. Sellers and purchasers are entitled to the certainty that their transactions are not only legal but will be respected locally and overseas, where sales laws may be different. Private international law also requires analysis when decision-makers must confront the differing treatment of post-theft transactions in various different jurisdictions for the purpose of settling restitution claims.

\subsection{Trafficking in Illicitly Obtained Antiquities}

News updates about illicit excavation and export of antiquities and archaeological materials are numerous ${ }^{95}$ and cultural trafficking has spiralled out of control. ${ }^{96}$ For example, tomb-raiding, relic smuggling and trading are rampant in $\mathrm{China}^{97}$ where bureaucratic corruption is rife. ${ }^{98}$ Unprofessional clandestine excavations are disrespectful of reporting standards. Antiques traffickers deface artefacts when this renders them less recognisable or easier to smuggle. ${ }^{99}$ Pottery and sculpture may be reduced to fragments or disguised as cheap souvenirs or modern material. Murals are cut into blocks. The ease with which cultural materials transit across certain strategic borders in intermediary or transit states ${ }^{100}$ is an additional worrying factor.

Traffickers devise many different ways by which to erase, cover and convert the illicit origins of objects, and present them as ready to be sold legally at destination. They have been known to conceal sites, obtain

95 The American Society of International Law provides regular updates, e.g. M Durney et al., 'Art and Antiquities Trafficking News Notes for May 2010October 2010’ (2010) 1 Cultural Heritage and Arts Review 57. The ICJP and International Lawyer also supply chronicles and reports.

96 Among many others see Ministerial Advisory Panel on Illicit Trade, Department for Culture, Media and Sport, 7th Report, December 2000; C Alder and K Polk, 'The Illicit Traffic in Plundered Antiquities' in P Reichel (ed), Handbook of Transnational Crime and Justice (Sage Publications 2005); SRM MacKenzie, Going, Going, Gone: Regulating the Market in Illicit Antiquities (Institute of Art and Law 2005); Tijhuis (n 54).

97 D Barboza, G Bowley and A Cox, 'A Culture of Bidding: Forging an Art Market in China' The New York Times (28 October 2013).

98 S Shiu-Hing Lo, The Politics of Cross-Border Crime in Greater China: Case Studies of Mainland China, Macao and Hong Kong (ME Sharpe 2009) 23.

99 I.e. export or import without the required authorisation.

100 E.g. Hong Kong, Singapore, Thailand and Finland. 
false permits to order excavation and export, ${ }^{101}$ and forge provenance ${ }^{102}$ in locations where this could increase commercial value ${ }^{103}$ or where opportunities exist for documented provenance to be generated. ${ }^{104}$ Falsified documentation enables eventual sales to be made to purchasers in good faith. ${ }^{105}$ Traffickers and dealers may also buy back objects at auction on the 'open market' to ensure objects have a specious provenance, and title can be laundered in this way. ${ }^{106}$

Clandestine removal and illegal export of previously undiscovered archaeological objects and other artefacts virtually guarantee that the objects will be damaged or even destroyed. When antiquities are looted directly from ancient habitation areas and burial sites, the loss of meaning and integrity (provenience) ${ }^{107}$ is irreparable ${ }^{108}$ because information about the excavation site and original context is lost. The removal of antiquities from the place they are found at in the source state poses issues for completion of historical record and for the preservation and restoration of cultural identity. With information on the find spot of the item in their excavation missing, the cultural affiliation of the object remains undecided, and the inherent value lodged in the historic, cultural and scientific information is irreparably injured. ${ }^{109}$ Reconstruction of the past then relies on piecing together the identities and location of local contacts, middlemen, procurers, transporters, dealers and criminals. ${ }^{110}$ Moreover, if the origin of an object is not immediately apparent, a dealer

101 Kingdom of Spain v Christie's 1986 WLR 1120 (further circulation of Goya's 'La Marquesa de Santa Cruz' prevented by the granting of the declaration sought by Spain that the export permit had been forged).

102 E.g. the Sevso Treasure, which purportedly came from the Lebanon, but which was moved under fake export licences. $\mathrm{P}$ Watson and $\mathrm{S}$ Todeschini, The Medici Conspiracy (Public Affairs 2006) 82.

103 Chappell and Polk (n 58) 105.

104 Switzerland's lax laws of import and export have long made it into a global warehouse and convenient trading post along the way. Several legal loopholes have now been closed, not least by the promulgation of the Federal Act on the International Transfer of Cultural Property of 2005.

105 Ulph and Smith (n 81) 258.

106 Term is explained below.

107 Chappell and Polk (n 58) 101; P Gerstenblith, 'The Public Interest in the Restitution of Cultural Objects' (2001) 16 Conn J Int L 197, 207, 245.

108 Gerstenblith (n 107) 203; Watson and Todeschini (n 102) 172-73.

109 Gerstenblith (n 107) 199.

110 Coggins (n 59) 70. 
or intermediary may pose as owner when transferring for value. Depriving the source state in this manner detracts from everyone's understanding of local and regional history. ${ }^{111}$ International quarrels about provenience become likely.

It is to be regretted that the aesthetic value of the vast majority of unprovenanced objects, such as the decorated pottery from Apulia, ${ }^{112}$ is used to compensate for lack of context. Information about scientific and historical context was considerably muted in the case of the Crosby Garret Helmet, which was found in Cumbria, England. Sensationalism can foster indifference to archaeological interests on the part of market players. ${ }^{113}$ The relationship between the aesthetic and economic spheres can also put pressure on business practice.

Most source states have not documented and excavated all their important sites, and need to do more to prevent further unsupervised and illegal excavations of sites on public or private land to supply objects to the art market. Such activities may be a last survival strategy for impoverished local people. Vulnerable sites are made all the more vulnerable by conflict, war, revolution or political distress. ${ }^{114}$ Paradoxically, however, looting and destruction may continue long after hostilities have dissipated, ${ }^{115}$ as the ongoing losses of cultural heritage in Cambodia and Afghanistan illustrate.

\subsection{Co-mingling of Licit and Illicit Trade}

The illicit trade is embedded within the licit art and antiquities trade. The trade tends to be open and licit in the major commercial centres, but the legitimate market intersects with the illegal market. Reliable data is hard

111 DC Lane, DG Bromley, RD Hicks and JS Mohoney, 'Time Crime: The Transnational Organization of Art and Antiquities Theft' (2008) 24 Journal of Contemporary Criminal Justice 243, 255; Cornu and Renold (n 77) 18.

112 More than 88 percent of Apulian pottery has no provenance. R Elia, 'Analysis of the Looting, Selling, and Collecting of Apulian Red-figure Vases: A Quantitative Approach' in N Brodie, J Doole, and C Renfrew (eds), Trade in Illicit Antiquities: the Destruction of the World's Archaeological Heritage (Cambridge 2001) 145.

113 Chappell and Polk (n 58) 101; Gerstenblith (n 107) 207, 245; <http:// www.bbc.co.uk/news/uk-england-cumbria-11287093> accessed 7 March 2014.

114 J Dietzler, "On "Organized Crime" in the Illicit Antiquities Trade: Moving Beyond the Definitional Debate' (2013) 16 Trends in Organized Crime 329, 340; Tijhuis (n 54) 135-37.

115 Tijhuis (n 54) 136. 
to come by, but the link is undeniable ${ }^{116}$ and the flows in the licit and illicit markets intermix. ${ }^{117}$ It is fair to say that the art and antiquities market is grey. ${ }^{118}$ Lines blur as a result of the movement, given that the identity which a cultural object fosters may change, and so may its status, category, function, physicality and meaning. ${ }^{119}$ The status and function of art and cultural objects may change not only with time, but also simply on account of being smuggled. ${ }^{120}$ The same activity may have a different status, depending on the jurisdiction and the characteristics of the objects. ${ }^{121}$ The status of an object may prove hard to verify in crossborder transfers that rely on a multidimensional network of trade, travel, banking, multinational entities and international regulatory bodies.

In combination with an acquisition-at-any-price culture, the co-mingling of legitimate sales with illicit transnational trade practices provide cover for those who wish to evade criminal responsibility. That scope exists for organised criminals ${ }^{122}$ to take advantage of the grey market was evident from the unsystematic excavations perpetrated in Italy to support the masterminds, dealers and middlemen of the Medici conspiracy. Not only are powerful dealers in a position to evade the legal obstacles of evidence and proof associated with criminal prosecution, but middlemen may confound law enforcement efforts by converting the status of the object or by navigating the applicable law in civil claims. ${ }^{123}$

116 OW Muscarella, The Lie Became Great: The Forgery of Ancient Near Eastern Cultures (Styx 2000) 1-29; Watson (n 80) 95; T Davis, 'Supply and Demand: Exposing the Illicit Trade of Cambodian Antiquities through a Study of Sotheby's Auction House' (2011) 56 Crime Law and Social Change 155ff; Tijhuis (n 54) 157.

117 MacKenzie (n 79) 72.

118 B Bowman, 'Transnational Crimes against Culture: Looting at Archaeological Sites and the "Grey" Market in Antiquities' (2008) 24 Journal of Contemporary Criminal Justice 225.

119 N Pearce, 'From Relic to Relic' [2013] Journal of the History of Collections 1, 3, 13 on the skull of Confucius; Schönenberger (n 43) 17 and Cornu and Renold (n 77) 17 on the Zuni Pueblo tribe and natural disintegration of certain objects.

120 C Roodt, 'Restitution of Art and Cultural Objects and Its Limits' (2013) 46 CILSA 286, 291.

121 Tijhuis (n 54) 129, 156.

122 MacKenzie (n 79) 69. In respect of forms of organised crime, see UN General Assembly Resolutions 66/180 and 68/186 on Strengthening Crime Prevention and Criminal Justice Responses to Protect Cultural Property, especially with regard to its Trafficking, A/Res/66/180 of 30 March 2012 and A/Res/68/186 of 11 February 2014.

123 MacKenzie (n 82) 136. 


\subsection{Demand, Supply and Regulation in the Illicit Trade in Cultural Objects}

Market participants keep the cycle of demand and supply going. ${ }^{124}$ Looters are driven by desperation and poverty to find objects and evade controls; smugglers by prospects for gain; ${ }^{125}$ middlemen by the exceptional incentives offered by the art trade; ${ }^{126}$ and collectors, who are part of the social elite, by their insatiable appetite for rare pieces of human history and the ancient contents of sites that can manifest their own wealth and enhance their status. ${ }^{127}$ Soaring prices incentivise smuggling and trade; after all, resale on the black market is always an option. ${ }^{128}$ Investors and cultural institutions with vast purchasing power contribute to driving up the demand for cultural material. Unscrupulous dealers tempt looters to offer antiquities to the market, while they entice collectors to invest. They have few qualms about passing on missing links in provenance to private and public collections that represent portals of entry to the legitimate world of trade in art. The purchaser's belief that an object is 'unique' enables a distinct market to form.

Finite, scarce and fragile objects are prizes in the quest for an instant personal history. The sense of belonging they provide contributes to the commoditisation of these objects.

Any remedies for non-compliance with acceptable standards of behaviour must be appropriate, while the effect of non-compliance-inducing factors should not be underestimated.

It would be erroneous to assume that an economic demand and supply approach necessarily condones the illicit trade. Demand and supply theory does not sit comfortably with measures that impede the free movement of legitimate antiquities, but it also values whatever adds to the value of an object - which includes a certified provenance for pieces. Unfortunately, while having to pay a high monetary value for the piece in question may ensure an interest in their physical protection, high yields

124 S Hutt, 'Cultural Property Law Theory' in JR Richman and MP Forsyth (eds), Legal Perspectives on Cultural Resources (AltaMira Press 2004) 17; JD Murphy, 'The People's Republic of China and the Illicit Trade in Cultural Property: Is the Embargo Approach the Answer?' [1994] IJCP 227, 234.

125 Murphy (n 124) 227, 229.

126 N Brodie, 'Pity the Poor Middlemen' (1998) 3 Culture without Context 7.

127 Chappell and Polk (n 58) 104, 111.

128 A Preston, 'Art Theft: Who's in the Frame? Why Steal a Priceless Masterpiece When It's Almost Impossible to Sell?' Daily Mail Online (9 February 2013). 
may also expose the archaeological record to harm. Additionally, source states tend to be permanently deprived of the long-term economic benefits of the cultural objects. ${ }^{129}$ An economic demand and supply approach is suitable when provenance is complete, databases for stolen cultural objects have been checked and authenticity has been confirmed. It is unsuitable, however, where sales continue amid cultural tensions or conflict, and when internet technology obstructs regulation.

Criminologists have studied the dynamics of the art trade with a view to devising models for improving regulation and the efficiency of law enforcement. Among other approaches, it has been suggested that 'sector vulnerability' is useful. 'Sector vulnerability' requires the rate of the illicit trade in cultural objects to be seen as connected to demand, supply, regulation and competition. ${ }^{130}$ Market reduction approaches operate on the basis that restriction of demand at the end-point of the market will reduce the supply. ${ }^{131}$ Market entry can be controlled by means of a strong regulatory component that keeps in check both the supply and demand sides of the trade. Routine activity theory draws attention to recurrent and prevalent adaptive activities of individuals and populations in specific social formations at a micro-level. ${ }^{132}$ Recurrent patterns of activity in any particular market can affect or corrode other sectors of the economy. ${ }^{133}$ Although opinion differs on whether routine activity theory is directly suitable to structural analysis of a transnational market, 134 the components which the theory identifies help to explain why criminal activity occurs. Whatever the motivation may be, art crime occurs when three factors converge: a suitable target; a motivated offender; and absence of effective guardianship or surveillance. ${ }^{135}$

Preliminary studies show that the route by which looted and misappropriated art and antiquities is taken depends upon their original location,

\footnotetext{
129 Bowman (n 118) 225; Durney and Proulx (n 85) 125.

130 MacKenzie (n 79) 75.

131 S MacKenzie, 'Identifying and Preventing Opportunities for Organized Crime in the International Antiquities Market' in S Manacorda (ed), Organized Crime in Art and Antiquities (2009 International Scientific and Professional Advisory Council of the UN Crime Prevention and Criminal Justice Programme) 41; Gerstenblith (n 107) 211.

132 Lane et al. (n 111) 244-45.

133 Lane et al. (n 111) 245.

134 Lane et al. (n 111) 244-45; contrast Dietzler (n 114) 336.

135 L Cohen and M Felson, 'Social Change and Crime Rate Trends: A Routine Activity Approach' 1979 (44) American Sociological Review 588; Durney and Proulx (n 85) 127.
} 
market demand and low levels of checks and security in carefully chosen transit states. ${ }^{136}$

The legitimate economy could be strengthened if source states ensured that these objects continue to fulfill their social roles and safeguarded opportunities for scientific research. They would be wise to adopt export licensing systems, impose reporting duties and reward those who report finds in order to regulate the supply. Source states do not control the reduction of market demand in market states, and many lack sufficient capacity for law enforcement. Nonetheless, they can also take steps to increase the likelihood of foreign courts recognising and applying the concepts and property categories in their laws that are affected by crime. They can enact clear state ownership laws ('vesting laws'). National ownership laws that are not predicated on common law preclude owners from acquiring title to antiquities found in the ground by providing that objects found after the entry into force of the relevant statute are the property of the state concerned. Vesting laws affect the marketability of looted antiquities among respectable dealers; because claims to these objects remain open under the 1995 UNIDROIT Convention on Stolen or Illegally Exported Cultural Objects, ${ }^{137}$ no time limit applies. The new Model Provisions on State Ownership of Undiscovered Cultural Objects promote the recognition of the validity of sovereign title claims under foreign vesting laws.

\section{RELEVANCE AND ROLE OF PRIVATE INTERNATIONAL LAW IN CONTROLLING CROSS-BORDER MOVEMENT AND TRADE}

The cross-border transfer of scarce cultural objects is likely if demand is high. The demand for antiquities vastly exceeds the shrinking legitimate supply. Suppliers (looters, dealers, middlemen) use or avoid the law in cross-border deals to advance their position in the market. Against this backdrop, the role which private international law can play to re-script the demand and supply cycles of the trade deserves investigation.

\footnotetext{
136 Lane et al. (n 111) 257.

137 See n 10.
} 


\subsection{Prerequisites for Achieving Justice ${ }^{138}$}

Under 5.1 above, the context in which civil claims are lodged was outlined. To succeed, pathways to justice are needed. Jurisdiction grounds that allow a national court to be seised and ADR facilitate justice. In case of a claim for restitution, the adjudicator requires an opportunity to receive and consider, on its merits, a request for return or restitution of an object that was retained or removed unlawfully. Jurisdiction in respect of confiscation or expropriation actions by the state within its own territory comes within the purview of the act of state doctrine and foreign immunity laws. A narrow interpretation of the exceptions to foreign immunity and the act of state defence can preclude a hearing on the merits. ${ }^{139}$

Depending on how a court deploys mechanisms such as classification and the public policy exception, choice of law method can grant (or preclude) an opportunity to rule on the merits of the case, and to enable (or disable) value-based decision-making. Once the object has been identified and the whereabouts of the possessor have been established, choice of law method can select among the potentially applicable legal systems one which recognises that crime voids the title transfer, or that the object bears an indelible taint until it is restored. ${ }^{140}$

If proceedings are pending in respect of a cultural object, it will be kept safe for the duration of the trial. The object will be detained and prevented from being removed unless anti-seizure legislation demands application. A court other than the one that has jurisdiction over the merits of the claim may be approached for provisional and protective measures that may apply extra-territorially. ${ }^{141}$

Restitution may be vital for the reconstitution of identity, among many other things. ${ }^{142}$ In the context of restitution claims, the 1995 UNIDROIT Convention indicates that a balance must be struck between numerous interests that condition the rules that could be applied and the risk of their impairment. The Convention demands the return of objects that

138 For more on conflicts justice, material justice, systemic justice and global justice, and the need to ensure justice in respect of ordering, norms and rights, see A Mills, The Confluence of Public and Private International Law (CUP 2010) $17 \mathrm{ff}, 303$.

139 Austria v Altmann 541 US 677-700 (2004). For more, see 6.3. Also Chapter 2 sub 6.4; and Chapter 4.

140 Chapter 5 returns to this aspect.

141 For more on these aspects, see van Woudenberg (n 9); Gillies (n 83).

142 Chechi (n 26) 33. 
have been stolen, but requires that the requesting or source state demonstrates any of the following interests: the physical preservation of the object or of its context; the integrity of a complex object; the preservation of information of, e.g., a scientific or historical character; or the traditional or ritual use of the object by a tribal or indigenous community.

The success of a restitution claim may depend on the recognition and application of provisions of public law designed to safeguard access to the object in question. Public display may be required and export prohibited. When the foreign provision claims application, the adjudicator requires an opportunity to check if mutual recognition would encroach on any forum interest and whether it would be internationally acceptable. ${ }^{143}$

The hurdles posed by the commercial imperative and the risk that the special nature of the object in question might go unrecognised, have been referred to above. Title laundering is an additional hurdle that will need to be identified.

\subsection{Title Laundering}

It has been observed that criminal activities involving art and clandestine excavation of antiquities have little in common. ${ }^{144}$ Art theft and clandestine excavation of antiquities differ in that clear title to art pre-exists the theft; with respect to previously undiscovered antiquities buried in the ground, the source state frequently assumes the status of legal owner only once state ownership legislation takes effect. By that point the crime may long be done and the context of the find damaged or destroyed. ${ }^{145}$ However, closer inspection reveals this differentiation to be inaccurate. Obvious commonalities include the attraction that both types of crime exert on those who are motivated by economic gain, and the fuel that revolution, war, conflict and state repression can provide for these activities. ${ }^{146}$ In addition, both are associated with a willingness to launder title. Where it can be proven that an object has been stolen, the object has to undergo the additional extra step of acquisition in good faith in a jurisdiction that protects good faith for laundering to be accomplished. ${ }^{147}$ Laundering may be accomplished through time limitations in respect of

\footnotetext{
143 Chapter 7 returns to this aspect.

144 Dietzler (n 114) 332; Tijhuis (n 54) 132-33.

145 Carducci (n 93) 77.

146 Tijhuis (n 54) 161.

147 Tijhuis (n 54) 187-88.
} 
the period within which an allegation of true ownership and a claim for restitution of the object must be brought before a court. ${ }^{148}$ Goods circulate more freely if the prior title of the owner is extinguished after a relatively short prescription period. ${ }^{149}$ A purchaser in good faith obtains security of title through adverse possession, ${ }^{150}$ prescriptive doctrines (including the 'laches' defence), ${ }^{151}$ and estoppel, ${ }^{152}$ since title is considered to have been transferred. Recovery is normally by means of claims in civil courts, where characterisation can give inadvertent support to laundering.

Those adept at title laundering distinguish between intermediary or transit states and end points in a transaction chain. ${ }^{153}$ Title laundering is facilitated when the status of a work of art or cultural object as stolen cannot be verified when crossing a border. Communication difficulties and lack of information exchange between market states and source states are common and will cause an object to be treated, for practical purposes, as a smuggled object only, as opposed to an object that had been stolen before it was exported. Smugglers benefit if regulation is lacking, criminal repercussions are limited, ratification of pertinent conventions such as the 1970 UNESCO Convention is delayed, EU law is ineffective, and policing in the end point is inadequate. ${ }^{154}$

The blurring of the distinction between licit and illicit trade facilitates title laundering further. Global legal diversity means that the legal status of objects depends on the jurisdiction in which trade takes place. There may be differences in crime definitions, laws and reporting duties as well

148 E.g. the reason why Robert Hecht was not successfully prosecuted for his part in the Medici Conspiracy in 2012, and why the heirs of George Grosz failed when they sued to have his works returned (Grosz $v$ The Museum of Modern Art, 772 F Supp 2d 473 (SDNY 2010); 403 Fed Appx 575 (2nd Circuit 16 December 2010); 132 S Ct 102; 181 L Ed 2d 30 (2011)).

149 G Reichelt, 'International Protection of Cultural Property' [1985] Uniform Law Review 42, 105ff, (reprinted as Study LXX Doc 1 Unidroit 1986); Prott and O'Keefe (n 19) 396ff.

150 Carducci (n 93) 69.

151 Solomon R Guggenheim Foundation v Lubell 77 NY 2d 311 (1991); Wertheimer v Cirker's Hayes Storage Warehouse, Inc., 752 NYS 2d 295 (Sup Ct 2002).

152 Autocephalous Greek Orthodox Church of Cypus v Goldberg and Feldman Fine Arts, Inc., 717 F Supp 1374 (SD Ind 1989) 1388.

153 E.g. the UK. See Koush (n 74) 16.

154 Tijhuis (n 54) 191, 203. 
as in respect of property law, statutory limitations and evidentiary law. ${ }^{155}$ No wonder the statistics about the volume and the value of art theft and the art trade are unreliable. ${ }^{156}$

The rectification of wrongful activity by means of civil remedies demands that we identify situations in which the law is liable to be used as a laundering device. Identification of opportunities for laundering will help more fully to realise the potential of private international law to constrain the illicit trade in cultural objects. Even when those opportunities are identified, the adjudicator's commitment to basing his or her decision on value rationality, may be challenged. Attention returns to this aspect under 7.6 below.

\subsection{Legal Systems in a Lock}

Criminological theories about the difficulty of distinguishing between the licit and the illicit trade tend to focus on the absence and evasion of regulation more than on the part played by particular jurisdictions and the effect of the passing of time in those jurisdictions. This study puts the primary focus on civil law, highlighting how private international law acts alongside other legal disciplines (commercial law, property law, public international law, human rights law and criminal law) to realize its role in respect of constraining the commercial imperative when purchasers and borrowers fall short of the minimum standards of ethical acquisition and collection in cross-border trade. Theories that account for title laundering, such as the 'lock' theory and the progression theory, are particularly relevant to this study.

The 'lock' model entails a description of the laundering mechanism, whereas the progression model enables study of the connections between activities and components in the 'lock' model at different stages of the trade. Both models enable analysis of title-laundering and leave room to discover how foreign law would affect the outcome of a case.

Tijhuis has developed a theory in respect of complexities associated with making a proper distinction between licit and illicit activities. ${ }^{157}$ This theory is significant because it accommodates private international

155 Durney and Proulx (n 85) 125, 127. For example, not all countries that report to Interpol record thefts by the type of object stolen. Many countries report by the circumstances of the theft.

156 N Brodie, 'Congenial Bedfellows? The Academy and the Antiquities Trade' (2011) 27 Journal of Contemporary Criminal Justice 408, 411; Tijhuis (n 54) 137-39.

157 Tijhuis (n 54) 129, $143 \mathrm{ff}$. 
law rules and devices, and allows room in which it is possible to show how they sustain the 'lock' mechanism. He distinguishes between the 'interface typology' developed by Passas, ${ }^{158}$ which can describe the mechanism of laundering the illicit art and antiquities trade, and the 'lock model', which he designed to explain the mechanism of entry into the licit market and its various parts. ${ }^{159}$ Individuals, companies, organisations and jurisdictions are different parts that combine variously to form 'locks' that transform the legal status of a certain activity. Examples of locks that 'launder' or clean title in a stolen object include an individual dealer who brokers deals with foreign purchasers on behalf of the Nazi regime; an individual who mediates between the robbers in one jurisdiction and the good faith purchasers in another; and a jurisdiction that remains on the outside of Conventions and lacks a proper regulatory framework and law enforcement. Lack of regulation and specialist policing in certain jurisdictions help those jurisdictions to operate as locks; ${ }^{160}$ while lax and tight regulation in different jurisdictions can combine to contribute to the formation of a lock. ${ }^{161}$ While open-border contexts where the political and economic infrastructure is weak may attract sellers, ${ }^{162}$ the complex interface of private law, private international law and treaty law as applied by states provides cover for traffickers and powerful dealers participating in global networks. Traffickers take advantage of the fact that title can be transferred in some jurisdictions in dubious circumstances. They may navigate the applicable law and launder title in ways that pre-empt civil claims. If provenance is not complete and apparent, a dealer or intermediary may pose as owner when transferring for value. If the origin of an artefact is disputed or it is unknown when excavation and export occurred, it cannot be established if laws that seem relevant will apply.

Locks are created when a jurisdiction provides a refuge for good faith purchasers, and private international law rules and devices sustain the mechanism. This is relevant in respect of a large number of unprovenanced pieces that are being traded post-excavation or after illicit

158 N Passas, 'Cross-border Crime and the Interface between Legal and Illegal Actors' (2003) 16 Security Journal 19. Symbiotic interfaces include facilitating, outsourcing, co-opting, reciprocity and legal interactions.

159 Tijhuis (n 54) 99ff, 191.

160 Tijhuis (n 54) 187.

161 Tijhuis (n 54) 162-65, 202-3 highlight case studies of sales of art and antiquities taken from France, by dealers, receivers and auction houses in the Netherlands and Belgium.

162 Dietzler (n 114) 339. 
exportation. If a trafficked object has been exported and absorbed into the international market, successful litigation implies proof of ownership and the enforceability of the claim. If a cultural object were stolen or misappropriated at any point, its ownership record is defective. The provenance argument relies on fact and inference based on intellectual, physical or forensic proof, or on scholarly deduction regarding the security of the chain of title. In legal discourse, provenance refers to record of title. ${ }^{163}$ At the same time, it does not equate to legality. Provenance is synonymous with legality only if a secure chain of provenance leads back to the moment of manufacture. The effect of a defect in the provenance on the purchaser will depend on which system of law is applicable and which legal family that system belongs to.

The progression model permits analysis of the sequence and connections between different jurisdictions. Felson has cautioned against underestimating how crime co-operation interacts with legitimate activities. He maintains that the problematic behaviour, the way in which events and behaviours are linked, their sequence, and the settings where actors meet in a criminal and organised market, warrant more attention than the groups that may be involved. ${ }^{164}$ The progression model builds on Felson's system. In addition to the separate factors that connect supply and demand settings and events, the progression model distinguishes between the mechanisms associated with transit, facilitation and trade, which may or may not come into play: (a) the theft by the looters at the site concerned; (b) the transit by smugglers at airports, ports or border checkpoints; (c) the possible facilitation of the transit at border checkpoints, ports, universities, museums, or embassies by means of forged documentation, laundering, corrupt officials, curators, academics and valuers who are complicit in the trade; and (d) the sale conducted by

163 'Provenance' discloses much more than ownership in curatorial discourse. Collection history, publication and exhibits are included. Among many other things, it also provides an account of changing artistic tastes and collecting priorities, a record of social and political alliances, and an indication of economic and market conditions influencing the sale or transfer of the work in question. <http://www.ifar.org/provenance_guide.php> accessed 24 February 2014. 'Provenience' would feature prominently in empricial archaeological discourse, whereas constructivist approaches are concerned with more than the origin or find spot of a cultural object.

164 M Felson, 'The Ecosystem for Organized Crime' (HEUNI Paper No 26, 20 October 2006) <http://www.heuni.fi/material/attachments/heuni/papers/6Ktm wqur9/HEUNI_papers_26.pdf> accessed 24 February 2014. 
dealers, purchasers, collectors at places such as homes, hotels and museums. ${ }^{165}$

This approach suggests that researchers and policy-makers ought to focus on the progression of the trade from source state to market state at different stages. It enables them to analyse the role, sequence and setting of parts of the trade that work on their own or together. ${ }^{166}$ The basic sequence of the progression can be 'analysed microscopically as individual ecosystems'. The links between the 'ecosystems' can be mapped. ${ }^{167}$ The progression model can help direct available law enforcement capacity to the stage of the trade in which a particular jurisdiction participates. ${ }^{168}$ It also allows room for considering the role played by private international law in the progression of the trade.

\subsection{Sovereign Acts of Expropriation or Confiscation Can Promote 'Lock' Formation}

It is unlikely that the validity of state confiscations pursuant to national laws (which may qualify as sovereign acts of state) can be successfully challenged within the territory of the expropriating state. When the objects that were confiscated by the state turn up in another jurisdiction they could be resold abroad for foreign currency, or they could be sold to a private owner who is abroad - testing the validity of these acts of state is possible. If the court recognises state ownership in these circumstances, the restitution action fails. ${ }^{169}$

Examples include the nationalisation of art collections during the Russian Revolution of 1917 and the more recent nationalisation laws passed by the Russian Duma in 1995 and 1997. A Federal Law on a Moratorium on the Return of Cultural Valuables Displaced in World War II of $1995^{170}$ applies to acts which occurred before the First Protocol to the Hague Convention for the Protection of Cultural Property entered into force. It confirms Russia's position on war reparations. The Federal Law

\footnotetext{
165 Dietzler (n 114) 338.

166 Dietzler (n 114) 329ff.

167 Dietzler (n 114) 340.

168 Dietzler (n 114) 338.

169 Schönenberger (n 43) 141. E.g. Yale University v Pierre Konowaloff, No. 3:09-cv-00466, stayed (D Conn 1 November 2011); granting summary judgment (D Conn 20 March 2014).

170 Decree of the State Duma of the Federal Assembly of the Russian Federation, 21 April 1995, Russian Federation Collection of Legislation, 1995, No 19, Item 1721.
} 
on Displaced Cultural Valuables of $1998^{171}$ was then passed in order to nationalise displaced cultural property located on Russian territory. The constitutional court forced the President to sign the law into operation. As was indicated, a restitution claim will fail if a foreign court recognises Russian state ownership as created in terms of these contentious laws. ${ }^{172}$ The theft and subsequent entry of Nazi spoliated art into the global art trade also introduced cross-border elements into dispute resolution processes that highlight several jurisdictional and normative aspects of restitution.

The 'lock' mechanism can engage jurisdictions that provide a refuge for good faith purchasers of confiscated objects. Switzerland frequently offered a reliable outlet. Articles 930-934 of the Swiss Civil Code173 extend favourable treatment to the possessor of a corporeal moveable, and if the possessor acquired in good faith and on the conviction that he or she would become owner, their rights are protected even if the transferor lacked authority to make the transfer. Moreover, several Swiss art professionals who were linked to top officials in the Nazi Party were willing to launder stolen art. Ordinary commercial or criminal law rules proved too general to deal effectively with claims based on confiscation, forced sales and sales at an undervalue.

Jurisdictions that extend recognition to state ownership based on expropriation may also form a lock. Such recognition can be extensive. For instance, courts are unlikely to question title in the wake of expropriation of the property of Russian nationals carried out by the Bolsheviks. ${ }^{174}$

Other laws can supply technical defences that impose limits on restitution claims, preventing them from being heard on their merits. For instance, there are legal systems that protect acquisition in bad faith after a certain length of time to draw a line under the matter, e.g. France and Germany. ${ }^{175}$ Statutory limitations tend to feature when the court classifies the cause of action (discussed below in 7.3).

\footnotetext{
171 Federal Law, 15 April 1998, no 64-FZ, Russian Federation Collection of Legislation, 1998, No 16, Item 1879.

172 AB Sargent, 'New Jurisdictional Tools for Displaced Cultural Property in Russia' [2010] Yearbook of Cultural Property Law 167, 173.

173 The Code dates from 10 December 1907.

174 See Princess Paley Olga v Weisz [1929] 1 KB 718 (CA) (nationalisation by the Soviet regime after the Russian Revolution).

175 Schönenberger (n 43) 140.
} 


\subsection{Criminal Law and Private International Law: Differences of Scope}

Criminal proceedings and co-operation treaties in criminal matters can result in the return of objects to their state of origin. For instance, Italy requested assistance from the US to obtain the return of the 'Atleta di Fano' (also known as 'Victorious Youth' or the Getty Bronze) in 2010, after an Italian forfeiture action was instituted in Pesaro. The Treaty on Mutual Assistance in Criminal Matters between Italy and the US176 appeared to be relevant, given that states do not automatically recognise and apply foreign criminal sanctions enacted in respect of illicit import and trade in stolen and illegally imported or excavated objects. This Treaty empowers federal district courts to execute requests to serve and produce documents, execute searches and seizures, take testimony and enables transnational forfeiture. Nonetheless, co-operation was ruled out due to the fact that Italy, the requesting state, itself never successfully prosecuted the offenders. The statutory limitation period had run out at the time. ${ }^{177}$

It is frequently assumed that a clear distinction between the scope of criminal law and of private international law of the forum state suffices. ${ }^{178}$ Consequently, the effect of the two disciplines on each other is seldom questioned. It is submitted that the potential of private international law can only be realized in disputes involving art and cultural objects if the various stages of the illicit trade, and the involvement of crime networks at various points in the trade, are firmly kept in view.

\subsection{Risk of Underestimating Private International Law}

The effect of private international law argument in litigated art and heritage claims has received independent scholarly attention. ${ }^{179}$ Prott predicted in 1990 that cultural heritage law would profoundly impact

176 Treaty on Mutual Assistance in Criminal Matters, US-Italy, 24 ILM 1536, signed 9 November 1982; entry into force 13 November 1985; Treaty on Mutual Assistance in Criminal Matters, US-Italy, signed on 3 May 2006.

177 A Lanciotti, 'The Dilemma of the Right to Ownership of Underwater Cultural Heritage: The Case of the "Getty Bronze"" in S Borelli and F Lenzerini (eds), Cultural Heritage, Cultural Rights, Cultural Diversity: New Developments in International Law (Nijhoff Publishers 2012) 301, 325.

178 Lanciotti (n 177) 316.

179 E.g. WW Kowalski, 'Restitution of Works of Art Pursuant to Private and Public International Law' 2001 (288) Recueil des Cours (The Hague 2002) 212-13; M Anton, Handbuch Kulturgüterschutz und Kunstrestitutionsrecht/ 
choice of law and its limits. ${ }^{180}$ Private international law was never expected to make a huge contribution to cultural heritage law, and expectations have remained low. ${ }^{181}$ The situation is partly due to the baffling, perplexing side of private international law. Its technical concepts and arguments can add to the risk of uncertainty and unsatisfactory results in litigation. ${ }^{182}$ Its reputation is not improved by the scholarly capacity for pallid, uncritical scholastic language. The assertion or denial of title, and trade in general, depend on the application of a determinate body of law, and this implies that choice of law rules (conflicts rules) will be applied when disputes arise. ${ }^{183}$ However, the logic of private international law argument can become overpowering and relentless ${ }^{184}$ when a small number of multilateral choice of law rules are fixated upon in the international art market. As long as the Organon of Logic operates on the basis of rules that are nationally conceived, contradictions and ethical questions cannot be satisfactorily solved. Paradoxically, to regard its scheme of logic as complete is to make it harder to see what private international law can offer in respect of the protection of art and cultural objects.

Both private international law and cultural heritage law are in search of comprehensive models and guiding principles to counter the illicit trade of art and antiquities. Both disciplines aspire to managing global legal diversity in a context of intermingling private and public law. The private international law argument, when offered, determines the rights of cultural institutions, owners, possessors, dealers and traffickers. Work of

Illegaler Kulturgüterverkehr (Handbuch Kulturguterschutz, und Kunstrestitutionsrecht) (De Gruyter 2010), Vols 3 and 5; E Jayme, 'Globalization in Art Law: Clash of Interests and International Tendencies' (2005) 38 Vanderbilt Journal of Transnational Law 927; S Symeonides, 'A Choice-of-Law Rule for Conflicts Involving Stolen Cultural Property' (2005) 38 Vanderbilt Journal of Transnational Law 1177; M Lee, 'A Choice of Law Dilemma: The Conflict and Reconciliation of Laws Governing Cross-Border Transfers of Stolen Art' [2008-2009] Cardozo Public Law Policy and Ethics Journal 719, 724; K Siehr, 'International Art Trade and the Law' VI (243) Recueil des Cours (The Hague 1993) 9; Jakubowski

(n 76) 137; Gillies (n 83).

180 Prott (n 26) 214; Jakubowski (n 76) 137, 138.

181 E.g. Last (n 8) 123.

182 E.g. Prott (n 26) 214; Chechi (n 26) 92, 105-6; Jakubowski (n 76) 137.

183 M Whincop and M Keyes, Policy and Pragmatism in the Conflict of Laws (Ashgate 2001) 108.

184 FK Juenger, 'Conflict of Laws: A Critique of Interest Analysis' (1984) 32 AJCL 1. 
this nature is already far advanced in Germany, for instance, ${ }^{185}$ but consistent work is required if we are to improve our understanding of its interaction and impact on cultural heritage law, on the one hand, and its capacity to offer market participants and adjudicators support in building global solidarity and welfare.

Private international law makes control measures available at the point of market demand. The practical control which private international law can offer as a regulatory tool for market states is considered next. It is vital to highlight how it can draw the cycles of supply and demand into closer alignment with ethical aspirations that contribute to a secure society.

\section{WHAT PRIVATE INTERNATIONAL LAW CAN OFFER CULTURAL HERITAGE LAW}

\subsection{The International Dimension}

Demand drives the looting of cultural material, feeds the black market and sustains the outflow of cultural materials. ${ }^{186}$ There are a large number of unprovenanced pieces being traded post-excavation or after illicit exportation. States struggle to adapt their legislation and provide appropriate standards for acquisition and trade. The popular doctrinal conception of sovereign national legal systems - at once competing for application and arbitrating that conflict - cannot constrain the commercial imperative. Conceived as a series or a set number of separate national conflicts rules that draw on national sources that invite competing representations of law, the method is supremely hostile to international norms and suppresses the public law dimension of the subject. ${ }^{187}$ In order to exert control at the demand side of the market, ${ }^{188}$ it must be possible to identify jurisdictions that operate as part of locks. The national conception cannot hope to keep up with the spectacular globalisation which cultural trafficking has undergone in recent decades.

\footnotetext{
185 Anton (n 179).

186 Durney and Proulx (n 85), 125; C Forrest, International Law and the Protection of Cultural Heritage (Routledge 2010) 156.

187 Mills (n 138) 3, 12, 243; F Rödl, 'Regime-Collisions, Proceduralised Conflict of Laws and the Unity of the Law: On the Form of Constitutionalism beyond the State' in R Nickel (ed), Conflict of Laws and Laws of Conflict in Europe and Beyond (Intersentia 2010) 263, 266-7.

188 Rödl (n 187) 268.
} 
Private international law was originally conceived as part of a universal law of nations. It was regarded as a set of secondary legal norms aimed at global legal ordering. ${ }^{189}$ Conceived as an 'internationalised' discipline that posits an international system, the subject can assume a unique role and function at the interface of universal norms and national norms. Its potential for unity comes from solving conflict by a higher ranking order, from simplifying the complex choices associated with international claims brought by private individuals or states.

\subsection{At the Point of Classification}

In international cases, classification is supposed to determine whether a particular issue is subject to the applicable law at all (it will be so only if it relates to the substance of the dispute). Depending on the classification, different legal systems could claim application. Is the underlying category the transfer of property or is it restitution? The type of claim instituted in international disputes depends on being classified into a particular type - the cause of action could be non-contractual (delictual/ tortious) or penal, a matter of transfer of real rights, a contractual obligation, a personal injury and so forth. ${ }^{190}$

Courts frequently use the property transaction as a basis for classification when art has crossed jurisdictional lines after having been stolen. When classified as a matter of proprietary transfer, legal diversity permeates the definitions, methods and conditions for valid transfer of title, levels of abstraction, approaches to organisation, and remedies for protection. ${ }^{191}$ Civilian jurisdictions differentiate between the contract directed at the transfer of rights and the actual transfer of a right from a transferor to a transferee by way of conveyance. If real rights can be transferred independently of any underlying legally recognised reason (causa) to pass the real right - as German law allows by virtue of the Abstraktionsprinzip - the system of transfer of real rights is abstract. If ownership can pass on mere delivery, an illegal contract cannot destroy the valid conveyance. ${ }^{192}$ In causal systems, which require a valid underlying basis for transfer (a valid agreement in rem or a 'real/proprietary contract' such as a sale), an illegal or invalid contract means the act of

\footnotetext{
189 Mills (n 138) 72, 117.

190 D Shapiro, 'Repatriation: A Modest Proposal' (1998) 31 International Law and Politics 95, 100.

191 Jakubowski (n 76) 140.

192 LPW van Vliet, 'Transfer of Movable Property' in JM Smits (ed), Elgar Encyclopedia of Comparative Law (Edward Elgar 2006) 730.
} 
conveyance will be void or voidable, depending on the circumstances. On this basis of ownership, the seller would be in a position to claim back what has been sold. Austrian and Swiss law fall into this category. ${ }^{193}$ There may also be a requirement of a proper or constructive delivery. Some sale codes are based on consensual conveyance. This is the rule in s 17 of the UK Sale of Goods Act. Ownership passes when the parties intend for it to pass, regardless of what may be agreed in respect of delivery or payment. The default position in terms of s 18 is that property passes when the contract is made. ${ }^{194}$ The differences between consensual systems and traditio systems are less stark than they seem at first; fictitious traditio and exceptions to the requirement of traditio have brought them closer together. ${ }^{195}$

Classification determines the effect of the passage of time on the claim; classified as a matter of substance, the same connecting factor and the same law will determine its effect. The connecting factor is a localising agent. It can relate to a person (domicile, habitual residence, nationality), a legal person (place of the central administration of a business when a contract was concluded), or the place of an event (place of contracting, place of performance, place of breach, place of wrongful action, place of damage).

This level of detail is hardly necessary to know, however, if the decision-maker were to treat classification as a step towards making a value-based decision. Ultimately, it is the value-judgement which the applicable legal system permits to be made in respect of restitution that is pertinent in claims involving art and cultural objects. In addition, if the decision-maker were to treat the distinction between substance and procedure in private international law as fluid and permeable ${ }^{196}$ rather than as a hard and fast line, a value-judgement can be facilitated. In English private international law practice, the basic distinction between substance and procedure leads, in one and the same case, to the application of rules belonging to different legal systems to the merits of the case and the conduct of the proceedings. Whereas matters of substance are governed by the law of the cause (the applicable law), matters of procedure are governed by the law of the forum (the court hearing the case). The basic substance/procedure distinction is widely

\footnotetext{
193 Van Vliet (n 192) 731.

194 Van Vliet (n 192) 730; LPW van Vliet, Transfer of Movables in German, French, English and Dutch Law (Arts Aequi Libri 2000) 111.

195 Van Vliet (n 192) 731.

196 R Garnett, Substance and Procedure in Private International Law (OUP 2012) 3 .
} 
assumed to be a matter of classification for purposes of traditional common law. The European Civil Law Model holds firmly to the dichotomy on the basis that differences in the nature of legal rules justify differences in their application in space. Rules that determine parties' rights and the merits of their arguments clearly differ from rules that support the smooth running of the court machinery. This model permits ready acceptance that the forum follows its own procedural rules in service of process, pleading and evidence, and allows the law of the cause to determine rights and liabilities. Thus, as in matters of procedure, it is to be expected that all evidentiary aspects will be subject to the law of the court hearing the case. At the same time, foreign procedural law can be taken cognizance of where procedural issues come into play.

A broad view of the scope of procedure leads to many foreign cases being decided on local procedural grounds, which, depending on classification, could include statutory limitations. Whereas a modest and functional definition of 'procedure' keeps procedural encroachments upon substance to a minimum, an over-inclusive definition fosters legal uncertainty. An over-inclusive definition of 'substance' bears a different kind of cost, namely that of proof of foreign law.

Expedience is the most commonly cited modern rationale for the distinction. ${ }^{197}$ The forum court draws the distinction for its own protection, for it cannot devote all its effort to adopting wholescale every intricate procedural rule of another state, even if that state's law governs the substance or merits of the dispute in hand. Nonetheless, the forum court is free to determine for itself how far it may go, without unduly inconveniencing itself, in applying the rules of the foreign legal system. ${ }^{198}$ If this freedom of the court to follow its own rules or the rules of a foreign court in matters of procedure, provided those rules are compatible with the authority and structure of the forum, ${ }^{199}$ is underplayed, claims involving art will not proceed to the merits stage. This obstacle poses a hindrance in many claims involving Nazi spoliated art, but the potential for merit-based decision-making inheres in the classification mechanism. This potential is at the disposal of adjudicators of cases involving cultural objects.

197 Garnett (n 196) 10.

198 WW Cook, 'Characterization in the Conflict of Laws' (1941) 51 Yale Law Journal 191, 201.

199 AV Levontin, Choice of Law and Conflict of Laws (AW Sijthoff 1976) $121-22$. 


\subsection{At the Point of Application of Foreign Public Law}

The effect of a cross-border transfer of a tangible cultural object could be that the original owner loses ownership rights; ${ }^{200}$ that the object loses its special status through non-recognition of the laws that are designed to prevent an object from crossing the boundary of public into private ownership; ${ }^{201}$ or that the state of origin might fail to enforce its export controls. ${ }^{202}$ Enforcement of import and export controls is polemical as a normative basis for international regulation, since a court may require a state to establish a property right in order to bring a claim. Common law, or an umbrella statute that vests ownership of undiscovered archaeological material in the state, represents a more readily accepted basis for a restitution claim. The lex situs rule, which refers to the law of the place where the object is situated at the time of transfer and which tends to dominate in questions of title transfer, can render the inalienability of a cultural object ineffective. ${ }^{203}$ This result can be prevented if the forum court were to decide to apply foreign public law protective of archaeological finds, ${ }^{204}$ export and import regulations for cultural heritage, ${ }^{205}$ and statutory declarations of state ownership of undiscovered antiquities that have left the state (vesting law). ${ }^{206}$ The recognition or application of a state claim to property will have the same effect as restitution of the

\footnotetext{
200 Winkworth v Christie Manson and Woods Ltd [1980] Ch 496.

201 Frias v Pinchon 1886 Clunet 593.

202 Attorney-General of New Zealand v Ortiz [1983] 2 All ER 93 (HL), affirming Attorney-General of New Zealand v Ortiz [1982] 3 All ER 451 (CA).

203 E.g. Frias v Pinchon (n 201). For more, see MA Renold, 'The International Protection of Archaeological Heritage: Questions of Private International Law and of Legal Harmonization' <http://biblio.juridicas.unam.mx/libros/7/3457/ 18.pdf $>$ accessed 11 June 2014, 297, 298-99.

204 Archaeological finds in Scotland belong to the Crown and are allocated to museums on the basis of their written claims. Museums may make ex gratia payments to finders. Scottish Archaeological Finds Allocation Panel, Treasure Trove in Scotland - a Code of Practice (Scottish Government 2008); Lord Advocate v University of Aberdeen \& Budge 1963 SC 533.

205 Attorney-General of New Zealand v Ortiz [1983] 2 All ER 93 (HL), affirming Attorney-General of New Zealand v Ortiz [1982] 3 All ER 451 (CA); (English conflict of laws espouses that foreign penal legislation will not be recognised and enforced in an English forum).

206 E.g. Egyptian Law 117 on the Protection of Antiquities of 1983. Art 6 declares all antiquities discovered in Egypt after 1983 to be the property of the Egyptian government, and which makes private ownership or possession of such objects illegal. US v Schultz, 333 F2d 393 (2nd Circuit 2003) cert denied Schultz $v$ United States, 540 US 1106 (2004).
} 
objects that were removed from its territory. Private international law has the potential to co-ordinate diverse national standards in the context of restitution claims based on vesting laws (see Chapter 7 below).

\subsection{Taking Account of Policy Interests in Choice of Law Method}

The intensification of connections between and among individuals, societies and economies provoke interpenetration of categories and interests - be they specific, general or international. Public interests embodied in legislation affect the choice of law process or push out the 'private' in private international law. To the extent that the classic divisions between public and private law relationships are blurring, the distinction between private and public international law comes to resemble an unrealistic principle of organisation. The notion of a global or transnational public sphere, and the overlap between international regimes and activities of state and non-state actors, support this idea.

The pressure of global legal diversity may be alleviated by the type of conflicts rule applied, or by allowing the policy underlying the rule to shape the outcome of its application. A choice of law rule indicates merely the legal system which is to supply the substantive relief or remedy sought in the particular case. Choice of law rules do not direct the forum to a particular substantive provision or decisional norm. They are not supposed to be directly concerned with the substantive outcome of disputes. ${ }^{207}$ Nonetheless, the legal relationship does not exist as an objective factor isolated from national interests and policies.

Orthodox multilateral private international law rules are frequently over-estimated and permitted to instil fixed conceptions of what counts as 'rule' and what counts as 'exception'. When this happens, these rules fail to promote value-based decision-making and produce mere instrumentalist or formulaic rulings.

Policy and value judgements shape private international law method especially in the US. The capacity of private international law to promote the role of law in the maintenance of a secure society can be explored more directly where substantive rules and their underlying policies enjoy prominence in conflicts theories, as is the case in the US. Federal choice of law is absent because federal institutions have withdrawn from this

207 JM Carruthers, The Transfer of Property in the Conflict of Laws (OUP 2005) §1.03. 
matter. The individual states are not in any position to provide impartial conflicts rules that would serve a federal system. ${ }^{208}$

While the US Constitution continues to have a low impact on choice of law, American conflicts thinking brings public interests squarely in view in private international law method. This tendency disturbs the multilateral method, on which European choice of law is predicated.

One way in which the US conflicts system takes public interests and policies underlying substantive rules into account, is by way of governmental interest analysis. ${ }^{209}$ Although eventually settled out of court in 2009, Schoeps v Museum of Modern Art ${ }^{210}$ illustrates the effect of interest analysis in the context of a claim to a Picasso painting, 'Boy Leading a Horse'. The painting had allegedly been transferred by a Jewish banker to his wife as a wedding gift in 1927. It was sent to Switzerland in 1933 and consigned to a Jewish art dealer in Switzerland in 1934, allegedly in response to Nazi duress. In 1936 it was sold on to an art dealer who bequeathed it to the Museum of Modern Art in New York. While the transfer of title in Germany could have been conceived as a consequence of duress to which German law could arguably apply as the lex loci delicti, New York law was held to have a more significant relationship to the parties and the painting. The court did not enquire into the quality of the causal link between Nazi persecution and the transfer of the work as it might have done, had it considered the potentially applicable laws to be German and Swiss law. New York law prevailed because the painting was shipped to New York immediately upon concluding the sale in 1936, remained there for more than seventy years, and was the property of a major cultural institution in New York. The interim transfer was considered to have been made at a temporary situs, meaning that Switzerland's interest in the application of its law was less compelling. The lex situs rule, which typifies many questions of title transfer, did not determine the outcome therefore.

\subsection{At the End of the Choice of Law Process: Public Policy Exception}

The public policy exception is an exception to the reference by a conflicts rule to a foreign legal system. This exception may prevent the

\footnotetext{
$208 \mathrm{~J}$ Basedow, 'Internal and External Conflicts, Federalism and Market Regulation: Federal Choice of Law in Europe and the US - a Comparative Account of Interstate Conflicts' (2008) 82 Tulane Law Review 2119, 2125.

209 SC Symeonides, 'The American Choice-of-Law Revolution: Past, Present and Future' (Martinus Nijhof 2006) 15-24.

210 Schoeps v Museum of Modern Art, 594 F Supp 2d 461 (SD NY 2009).
} 
selected law from applying and may clear the way for the law of the court to apply. Public policy is a fluid concept that derives from domestic, regional and international law. It evolves along with a particular state's legal and social norms. The exception operates as a 'safety valve' that bars the application of an otherwise competent foreign law when it conflicts with a more fundamental public policy of the forum. It operates defensively in its traditional (common law) role as a 'weapon of last resort'. It is employed at the end of a forum's choice of law process.

The public policy exception defines the outer limits of the tolerance of difference enabled by choice of law rules. When global, national, private, object and market interests compete or clash, this device enables the adjudicator to put the protective values of the forum first. It marks the point at which a court may refuse to support pluralism. ${ }^{211}$

Limits that could signal non-application of the foreign law are found in public interests and the social order of the forum (e.g. expropriation, confiscation of the property of alien nationals or money laundering); in the regulation of the national economy (e.g. import and export regulations); in morality (e.g. handling stolen property or illicit trading in cultural property); or in public law intervention in international transactions (e.g. currency legislation). When the potentially applicable foreign law does not conform with fundamental rights conceptions, the displacing role of the public policy exception intensifies. ${ }^{212}$

In turn, local public policy is also subject to limits. For instance, it is constrained by the norms of international law. These limits prevent it from undermining justice pluralism. In a federal system, it has a lesser role because of stronger obligations of mutual respect. Whether the public policy exception is invoked ought to be subject to considerations of proximity and relativity: the proximity or connection between the state and the dispute, and the severity of the breach of public policy. ${ }^{213}$

Theoretically, when the public policy exception is invoked, what remains of the applicable law should be applied. In practice, local law is applied (because the forum uses appropriate local provisions in lieu). Ideally, if an ethical dimension is to assume relevance, the law that best advances global welfare should be applied (see 7.6. below).

In figure-ground perception, the policy position can function either as 'figure' or as 'ground'. In the multilateral choice of law method, the multilateral choice of law rule will necessarily function as 'figure',

\footnotetext{
211 Mills (n 138) 191.

212 B Fauvarque-Cosson, 'Comparative Law and Conflict of Laws - Allies or Enemies?' (2001) 49 AJCL 407, 409-10.

213 Mills (n 138) 191, 306-7.
} 
leaving the public policy exception to form the ground. Perception can shift. The public policy exception can function as the 'figure' when it is conceived as a 'rule' that attends to the substantive content of the applicable law to check if the content is detestable, or when it is regarded as an exceptional choice of law rule that prioritises the local law of the forum as embodied in its public law. Perceiving the policy position as 'figure', a court may protect a vital state interest in the social order. The multilateral choice of law rule becomes 'ground' and its role can be qualified in accordance with this perception. Public policy asserts itself in this 'positive' way, when unilateral or mandatory rules are used to override choice of law rules prior to their application, or where the court insists on the application of a law that would not be applicable otherwise (forum law or even foreign law). ${ }^{214}$ Arguably there are in-between possibilities, depending on public policy laws and public interests (wider in meaning than 'laws') where the application of the relevant choice of law rule is qualified, that are better suited to respond to a particular state policy.

In New York, for instance, courts do not permit the state to be used as a haven for stolen cultural property; their interpretation of the lex situs rule is qualified in accordance with this priority. Chapter 5 illustrates how the choice of law methods play out in disputes involving stolen cultural objects when a global lens is applied. Mutual recognition of the exclusive reference to forum law produces a new type of unilateralism that can ultimately foster co-operation between nations, build international solidarity and make room for the comity of nations (in the sense of respect and recognition of the legislative, executive and judicial acts of a foreign government). Even where the lex fori is the only point of reference, made at the end of the choice of law process, global welfare is served when mutual recognition of forum law follows. The result is similar to having applied the unilateral method (see 6.2 above). ${ }^{215}$ In Europe, it is conceivable that protective national rules could qualify for application provided they are re-characterised and do not infringe on European law.

While the consistent legal treatment of international cases of the same type is an unachievable goal, it is the pursuit of the goal that keeps the method on track. Without it, theoretical and methodological approaches in private international law can be over-estimated, and the orthodox multilateral private international law rules will be treated as something

214 Regazzoni v Sethia [1958] AC 301 (HL). TC Hartley, International Commercial Litigation: Text, Cases and Materials on Private International Law (CUP 2009) 514.

215 Directive 2014/60/EU, Recital 6. 
other than the manifestations of international norms they are. Fixed conceptions of what counts as 'rule' and what counts as exception pose obstacles on the way towards consistent treatment.

\subsection{When Ethics Demand a Place Alongside Private International Law}

Museums, galleries and collectors should only be acquiring material with reliable documentation that confirms that the object had left its country of origin before a legal prohibition of export was enacted in that country or otherwise in accordance with the law. In practice, however, collectors frequently fail to make contact with foreign authorities before they acquire objects. Ethics cannot be legislated, nor concern for the market forced, but ethics have a bearing on the standards applicable to the acquisition of pieces lacking a discoverable, documented or complete provenance. Ideally, a secure chain of title leads all the way back in time to the date of manufacture, production or excavation.

Many states adopted legislation to regulate state ownership and export in the mid-twentieth century. ${ }^{216}$ For those that did not, the international 'cut-off' date for the trans-border movement of pieces without a proper collecting history would be 1970.217

The highest aspirations of society are found in commitments to support provenance research, development of databases that facilitate independent searches, norms (hard law) and codes of conduct. It is desirable to make full use of the law to control and to rein in market activity, when ethics so require. Ultimately, there are legal and non-legal factors that facilitate the global and widespread illicit trafficking of art and cultural objects. Factors such as legal diversity can affect the chain of ownership, but there may be non-legal factors that encourage problematic behaviours. Realism demands keeping both the legal and the non-legal factors in view, in order that behaviours can be modified and adverse effects countered.

216 P Craddock, Scientific Investigation of Copies, Fakes and Forgeries (Elsevier 2009) 21.

2171970 UNESCO Convention on the Means of Prohibiting and Preventing the Illicit Import, Export and Transfer of Ownership of Cultural Property 14 November 1970, 823 UNTS 231; 10 ILM 289. MM Miles, Art as Plunder: The Ancient Origins of Debate about Cultural Property (CUP 2008) 355. 
Ethical action may not be legally required in every jurisdiction. The standards of due diligence 218 differ across jurisdictions ${ }^{219}$ and depend on whether criminal or civil remedies are being pursued. Nonetheless, due care never ceases to be an option. The potential buyer may always choose to consult a commercial, international or state-run database. ${ }^{220}$ It will always be vitally important to enable those buyers, dealers and auction houses that take responsibility for the art market to conduct searches and run checks before buying or selling. Given that there are market participants who choose to take responsibility for the market, database checks are one of the best ways in which to control the spill-over effects of the market onto source states.

Since the problem of dubious acquisition practices has an ethical dimension, the most suitable response is through a normative ideal that can bring market activity into alignment with a framework that keeps unbridled self-interest in check. This is so because non-legal standards affect compliance with legal obligations. As was stated above, acquisition standards and the duties of market participants do not derive only from law. In fact, the notion that the law is the source and origin of these behavioural standards deserves to be challenged.

It is essential to draw attention also to the limits of the law. For instance, relevant international instruments do not provide standard autonomous definitions of undesirable conduct. They cannot ensure adequate support for curators and museums. They cannot guarantee the safety of archaeological sites. They cannot compel the public and private sector of the state parties to devise successful multi-jurisdictional art loss

218 Principle 2.3 of the Code of Ethics of the International Council of Museums (ICOM) 1986 as amended refers to the duty to discover the full history of an item since discovery or production. The glossary refers to ' $[\mathrm{t}]$ he requirement that every endeavour is made to establish the facts of a case before deciding a course of action, particularly in identifying the source and history of an item offered for acquisition or use before acquiring it'.

219 See Chapter 2, sub 4.2.2.

220 E.g. the INTERPOL Stolen Art and Antiquities Database; London Stolen Arts Database; Leonardo Database (specialist police database of stolen works of art used by the Italian police art and heritage protection squad, which is also the largest European database); International Observatory on Illicit Traffic in Cultural Goods (ICOM) (designed to counter the lack of centralized information on illicit traffic in cultural goods; operational since July 2013, and funded for 3 years). WWII provenance research resources include the Art Loss Register; Central Registry of Information on Looted Cultural Property, 1933-1945, administered by the Commission for Looted Art in Europe; and the Lost Art Internet Database. 
registers. $^{221}$ No convention can make up or substitute for an inefficient cultural policy at home. The law cannot even impose a permanent illegal status on an item. It can only proscribe particular behaviour ${ }^{222}$ such as theft, looting, forced sale, unprofessional and unsystematic excavation and illegal export as defined in domestic legislation.

Never are the limits of law more evident than in the countless uprooted and fragmented lives lived in communities in states at war or caught in circumstances of social and economic upheaval. All 'markers of culture' are affected by conflict. ${ }^{223}$ Culture is under perpetual threat and its fruits traded willy-nilly. Modern conflicts directly open new sources of cultural heritage for looting, as the conflicts in Palestine, Afghanistan, Iraq, Egypt and Syria demonstrate. ${ }^{224}$ The ways in which cultural objects are sometimes destroyed are indicative of a cultural heritage crisis. ${ }^{225}$ The destruction of the Bamiyan Buddhas in Afghanistan in March 2001 at the hands of the Taliban was a particularly disturbing example that flies in the face of the basic principle that cultural property has partial immunity from seizure. ${ }^{226}$ The 1954 Hague Convention for the Protection of Cultural Property in the Event of Armed Conflict ${ }^{227}$ is protective of cultural diversity. It requires the safeguarding of cultural property during

221 Siehr (n 179) 279.

222 K Alderman, 'The Ethical Trade in Cultural Property: Ethics and Law in the Antiquity Auction Industry' [2008] ILSA Journal of International and Comparative Law 1, 13.

223 Ulph and Smith (n 81) 258.

224 E.g. M Bogdanons, 'The Casualties of War: The Truth about the Iraq Museum' (2005) 109 American Journal of Archaeology 477; J Halperin, 'Egypt's Malawi Museum Ransacked' The Art Newspaper (21 August 2013); T Ghose, 'Syria's Civil War Imperils Nation's Rich Archaeological Treasures' NBC News (4 September 2013).

225 Gerstenblith (n 33) 78-83.

226 The first statement with actual legal force was Instructions for the Government of Armies of the United States in the Field (Lieber Code), 24 April 1863, promulgated as General Orders No 100 in 1863 (Washington 1898: Government Printing Office); Regulations annexed to 1899 Hague Convention II and 1907 Hague Convention IV Concerning the Law and Customs of War on Land (Arts 27 and 56); Hague Convention IX concerning Bombardments by Naval Forces in Time of War, 18 October 1907, 36 Stat. 2351 (Art 5); Washington Treaty on the Protection of Artistic and Scientific Institutions and Historic Monuments (Roerich Pact), 15 April 1935, 167 LNTS 289; entry into force 26 August 1935.

227 The Hague, 14 May 1954. 
occupation or during war, but recognises that the cultural damage wrought during World War II proved the inadequacy of existing rules.228

Tolstoy concluded What Is Art with a profound realisation concerning the enormity of the task of art: "Art should cause violence to be set aside. And it is only art that can accomplish this.' 229

He noted sombrely that when art fails to fulfil its task, co-operation is obtained only through law courts and law enforcement agencies. This perspective has some bearing on the method adopted for purposes of this inquiry. Art and cultural objects possess the capacity to promote a shared sense of community in a pluralist world. ${ }^{230}$ To the extent that they reach past the physical aspects of being human to encourage 'intercultural respect' that makes 'a culture of peace', ${ }^{231}$ they are an inspiration in the search for dispute resolution.

\title{
7.7 Global Solidarity: How Does Private International Law Contribute?
}

Global solidarity is built on a normative ideal with a moral aim located in the cultural sphere. ${ }^{232}$ Illicit trafficking and unethical trade in cultural objects and looted art is a global issue that requires co-ordinated international action. The achievement of the normative ideal, whether by legal or by non-legal means, presupposes the development of key human potentials, including the potential for rationality and for mutual respect and co-operation. At the international level, the same human potentials are required - rationality, mutuality and realizing that the welfare of a single state is connected to the welfare of every state.

The ideal of solidarity points towards a demanding step-up in rational decision-making, because its achievement requires value-rationality. ${ }^{233}$

\author{
228 Gazzini (n 75) 3. \\ 229 Tolstoy (n 4) 210. \\ 230 PM Bator, 'An Essay on the International Trade in Art' (1982) 34
} Stanford Law Review 275, 307; E Jayme, 'Neueste Entwicklungen im Internationalen Kunstrecht' in Kunst im Recht (Graz Jurisprudential Faculty 2004) 15; Van Woudenberg (n 9) 15-16; JP Fishman, 'Locating the International Interest in Intranational Cultural Property Disputes' (2010) 35 The Yale Journal of International Law 347, 389, 393.

231 UNESCO Convention on the Protection and Promotion of the Diversity of Cultural Expressions (n 11).

232 Wilde (n 71) 64-67, 105.

233 For more on the difference between instrumental and value rationality, see Wilde (n 71) 119-20, 191ff. 
Value-rationality refers to ethical action taken irrespective of the prospects of success; acting in accordance with mutuality even when the prospects of success are low, and even when private fairness and convenience indicate otherwise.

The ways in which claims for restitution of trafficked objects and of stolen, looted or misappropriated cultural objects are dealt with can either exacerbate the problems associated with the ethics deficit in acquisition practices, or can strengthen global solidarity and the aspirations embodied in instruments of international policy. The settlement of claims in the spirit of global solidarity requires insight into the options for dispute resolution and demands a step-up in the approaches and methods that prevail today.

In the light of the above, the true measure of the success of any method that purports to have something to contribute to cultural heritage law, is its ability to promote impeccable, clear acquisition standards; foster a deeper commitment to value-based rationality; and control the spill-over effects of the market demand onto source states. Private international law offers tools that can prove useful here, but then these tools are to be used advisedly. If the adjudicator succumbs to pure techniques of law and artificial procedural considerations that confine the scope for value-based decision-making, these tools will come to nought. Pure technique deserves to be questioned, and with consistency. ${ }^{234}$ Legal instrumentalism poses as big a hurdle to protection, as the complex nature of art and cultural objects and the co-mingling of the licit and the illicit trade do. Sustained systematic academic scrutiny must identify why value choices fall by the wayside and suggest ways in which to counter practices that preclude proper consideration of values.

Choice of law methods can work in tandem with public law and public international law when the perspective on the interaction between different systems of civil justice draws on global welfare. ${ }^{235}$ This opportunity

234 A Carty, Philosophy of International Law (Columbia University Press 2007) questions the use of legal technique and instrumental decision-making in public international law. Arguably, it is vital to make room for the ethical dimension of society in public international law also, given that pure techniques of law limit the scope for value-based decision-making.

235 For more on the significance of global solidarity and welfare in private international law, see $\mathrm{H}$ Muir Watt, 'Choice of Law in Integrated and Interconnected Markets: A Matter of Political Economy' (2003) 9 Columbian Journal of European Law 383, 405. For more on the significance of these concepts in international relations and in public international law, see Wilde (n 71) and Carty (n 234) (Chapter 8) respectively. 
arises when the classification mechanism is applied, in the context of the public policy exception, and when policy and substantive interests and values must be accommodated.

The avoidance of value-based decisions by classification - e.g. classifying statutory limitations or prescription as a matter of procedure to be governed by the law of the forum - generates pressure in an area where global solidarity is sorely needed. This tendency affects the success of claims involving Nazi spoliated art.

The post-war restitution cycle, which was intended to address the Nazi spoliation in Europe in the 1940s and 1950s, had a strict national legal thrust. German and Austrian post-war laws repudiated all spurious 'transactions' of this era, including art 'deals' that were made to appear legal. These repudiations came soon enough after World War II ended, and never qualified for protection as acts of state. ${ }^{236}$ It has been argued that a new openly moral and policy-based cycle of restitution was born after $1989 .{ }^{237}$ Since then it has been recognised that compliance with the law could not always function as a precondition to restitution. ${ }^{238}$ If a more openly policy-oriented and ethics-driven approach to restitution processes were to take root, the meaning of 'restitution' would extend to instances in which the legal obstacles in the way of return must be overcome. 239 This understanding seems accurate. Legal grounds for confiscations and the obstacles they presented to restitution were already being addressed in different post-war municipal laws at the end of World War II. ${ }^{240}$ In special regulations for the return of Nazi-induced losses in Austria, Germany and Switzerland, return was indicated regardless of good faith or adverse possession. ${ }^{241}$ The criteria and procedures of the national mediation commissions that operate in five EU Member

236 Republic of Austria v Altmann, 541 US 677, 682 (2004); Majken Hofmann, Anna Lokrantz, Maria Müller, Andreas Müller Hofmann und Lena Müller Hofmann $v$ Republic of Austria (Nov. 21, 2005)(Arbitral award in German) <www.bslaw.com/altmann/Zuckerkandl/Klage/284724.doc> accessed 24 February 2014; US v Portrait of Wally, 2002 US District LEXIS 6445, 25ff; Schönenberger (n 43) 202-3.

237 Tijhuis (n 54) 2-3.

238 W Veraart and L Winkel, 'An Introduction to Dilemmas of Post-War Restitution in Europe' in W Veraart and L Winkel (eds), The Post-war Restitution of Property Rights in Europe (Rvp Press 2011) 1; Cornu and Renold (n 77) 15.

239 Veraart and Winkel (n 238) 2; Schönenberger (n 43) 228.

240 Schönenberger (n 43) $201 \mathrm{ff}$.

241 Schönenberger (n 43) 221. 
States $^{242}$ signal significant progress in this regard, even if their recommendations are ad hoc and case-by-case.

Mutuality may pose an issue in an action to recover moveable property in another state when the forum state reserves its position on the application of foreign public law. ${ }^{243}$ As Chapter 7 demonstrates, global solidarity counters the non-recognition argument. Source states, market states and states that operate at both ends of the spectrum can build global solidarity by their willingness to harmonize their responses in the interest of global welfare. Arguably, this willingness is less a matter of legal obligation than it is of human potential for co-operation for purposes of the effective control and counter-action of the illicit trade.

The potential of private international law to contribute to global solidarity deserves to be utilised alongside that of international law and criminal law, and in addition to money-laundering regulations and administrative procedures concerned with import and export controls. ${ }^{244}$ Private international law does not take the place of other manifestations of global solidarity, such as social movements that are informed about global issues. Specifically, it does not purport to supplant the solidarity that is built on a normative ideal with a moral aim located in the cultural sphere. Private international law could never achieve more than the voluntary return of an unprovenanced cultural object could. For example, two artefacts that belong to the 'Benin Bronzes' collection'245 were returned to the King of Benin in Nigeria in 2014, after the heir discovered more about their role in Britain's colonial history, namely that the testator had taken part in the British Punitive Expedition at Benin in 1897.246

Ultimately, Tolstoy is right about the law being but an external means. Our interior lives can accomplish so much more. ${ }^{247}$ Yet, the external protection offered by the law may strengthen the ethical framework and the solidarity that precedes it. It may also create a more favourable

242 Meeting of Five European Committees, Symposium in the Peace Palace in The Hague, 26/27 November 2012, <http://www.restitutiecommissie.nl/en/ committees.html> accessed 25 February 2014.

243 See Chapter 7.

244 Among others Forrest (n 186) 219; Ulph and Smith (n 81) 101-45 (controls in the UK).

245 For more, see <http://www.britishmuseum.org/explore/highlights/high light_objects/aoa/b/benin_plaque_oba_europeans.aspx> accessed 20 July 2014.

246 AFP, "Looted" Nigerian Art Returned to Traditional Ruler' South African Courier (23 June 2014).

247 Tolstoy (n 4) 210. 
environment for 'cultural diplomacy'. This concept includes the mutual understanding that art and culture foster, as well as the global understanding that collaborative excavation and research projects, exhibitions, loans, and knowledge exchange can offer. ${ }^{248}$ Italian soldiers took the Obelisk of Aksum (3 BCE) from Ethiopia in 1937. It was due to be returned under an agreement reached in 1947. Regrettably however, it remained in Rome for 68 years, to be restituted only in 2005. Clearly, cultural diplomacy stands no chance if co-operation and mutuality are lacking. ${ }^{249}$

An appreciation of the wider context for dispute resolution helps to provide perspective on what private international law can offer. Because litigation is not always the best procedure for return, and restitution frequently depends on value-based decision-making, the use of alternative dispute resolution mechanisms (ADR) has gained more prominence. ${ }^{250}$

\section{WIDENING THE FOCUS TO ENCOMPASS DISPUTE RESOLUTION}

\subsection{ADR}

Courts are not always regarded as ideal fora to decide disputes involving art and heritage, because there are discrepancies between state law and practice and irreducible differences between different legal families and legal cultures which domestic choice of law rules can struggle to overcome. A 'national' private international law could mean that the systemic effects of applying certain conflict rules become amplified and adaptations hard to make. The protection and enforcement of state (sovereign) interests may distort the process of dispute resolution and the

248 Kuprecht and Siehr (n 70) 270; I Stamatoudi, Cultural Property Law and Restitution (Edward Elgar 2011) 208.

249 Wilde (n 71) 105, 117ff. For examples, see <http://www2.mcdonald. cam.ac.uk/projects/iarc/culturewithoutcontext/issue10/watson.htm> accessed 24 February 2014 (return of the head of Amenhotep III to Egypt); S Knapton, 'Smuggled Ancient Sculpture Returns to Egypt' The Telegraph (19 December 2008).

250 M Granovsky, 'A Permanent Resolution Mechanism of Cultural Property Disputes' (2008) 8 Pepperdine Dispute Resolution Law Journal 25; AL Bandle and S Theurich, 'Alternative Dispute Resolution and Art-Law - a New Research Project of the Geneva Art-Law Centre' (2011) 6 Journal of International Commercial Law and Technology 28. 
outcome of an international judicial ruling may not be what communities and groups would regard as just.

Claims for return are frequently resolved extra-judicially. ${ }^{251}$ Negotiation and mediation have made their mark. For instance, the settlement of the intra-national dispute between St Gallen and Zürich over the territorial removal of books, paintings, manuscripts and astronomical instruments during times of war suggests that the cumulative application of various different techniques for dispute resolution enabled an amicable solution to be found. ${ }^{252}$ Mediation by the Swiss Confederation resulted in restitution in the form of a long-term loan, a donation, the production of a replica, and there was formal recognition of the importance of certain objects to the identity of the counter-party. State-run mediation can offer wide-ranging solutions which may include the continuance of an existing business or professional relationship or an agreement to take some action without any existing legal obligation to do so. ${ }^{253}$ The jurisdictional scope within which judges operate does not permit such unconventional remedies. Typical hurdles in litigation may be overcome because special mediation processes take account of highly specific subject matter, and of commercial, cultural, ethical, historical, moral, religious and spiritual aspects.

The nature of the remedy that the claimant seeks in a dispute over ownership and possession gives some indication of the most appropriate dispute resolution mechanism to be followed. Independent mediation (which is not state-run) seeks to resolve disputes on an informal basis by a neutral intermediary who assists the parties to identify common ground. Successful independent mediation may yield a settlement agreement with tangible outcomes that can be enforced under contract law. ${ }^{254}$ It is vital to identify the best stage at which to mediate. If it is embarked upon too

251 See the database set up by the Art-Law Centre of the University of Geneva under the name ArThemis, <http://unige.ch/art-adr> accessed 24 February 2014.

252 Cornu and Renold (n 77) 12, 18.

253 Halsey v Milton Keynes General NHS Trust [2004] 1 WLR 3002 (CA) 3008-9 (mediation in a damages suit).

254 JC Wichard and WB Wendland, 'Mediation as an Option for Resolving Disputes between Indigenous/Traditional Communities and Industry Concerning Traditional Knowledge' in BT Hoffman (ed), Art and Cultural Heritage: Law, Policy and Practice (CUP 2006) 477. 
early, the parties will be insufficiently informed about each other's cases; if it starts too late, high costs may already have been incurred. ${ }^{255}$

If the form of the mediation in question focuses on the needs and interests of the parties (e.g. if facilitative mediation is used), future relationships and goals are considered to be more important than redress of past conduct. ${ }^{256}$ The goal may be different in evaluative or transformative mediation.

The capacity for dispute resolution through ADR and by having recourse to an international tribunal is weakened to an extent by being consent-based. Consent may be absent when gaps become apparent in the provenance of the work after its acquisition in good faith, and noncompliance with the outcome entails no sanction. ${ }^{257}$ In the event of non-compliance with the outcome of independent mediation, contractbased court action would be necessary.

If a state entity is involved, consent is a moot point. If the parties are bound into state-run mediation, their autonomy to choose any ADR option is curtailed. The accountability structures for state entities may not permit them to opt out of the mediation and enforcement of the agreement against a state-entity is unlikely to end up in a state court.

\subsection{Arbitration}

Arbitration of claims to cultural property has been an appealing possibility for commentators ever since the 1990s. ${ }^{258}$ Over the last decade, more sustained and critical work has been done in respect of this form of dispute settlement. ${ }^{259}$ Arbitration is no panacea, however. The purchaser

255 Lord Jackson, Review of Civil Litigation Costs: Final Report (1st edn, The Stationery Office 2010).

256 N Palmer, 'Litigation: The Best Remedy?' in International Bureau of the Permanent Court of Arbitration (Hrsg.)(ed.) Resolution of Cultural Property Disputes (The Hague 2004) 113.

257 A Chechi, 'Some Reflections on International Adjudication of Cultural Heritage-Related Cases' (2013) 10 TDM Special Issue 1, 7.

258 EI Gegas, 'International Arbitration and Resolution of Cultural Property Disputes' (1997) 13 Ohio State Journal on Dispute Resolution 129, 151ff; E Sidorsky, 'The 1995 Unidroit Convention on Stolen or Illegally Exported Cultural Objects: The Role of International Arbitration' (1996) 5 IJCP 19.

259 Gazzini (n 75) 50; BW Daly, 'The Potential for Arbitration of Cultural Property Disputes: Recent Developments at the Permanent Court of Arbitration' [2005] Law and Practice of International Courts and Tribunals 261; N Palmer, 'Arbitration and the Applicable Law in Resolution of Cultural Property Disputes' in International Bureau of the Permanent Court of Arbitration (ed), Resolution of 
of a cultural object may suddenly be caught 'between' different adjudicatory procedures if the true owner institutes a suit while there is an arbitration agreement between the purchaser and the seller. The court and the arbitral tribunal adhere to the rules and conventions of decidedly different legal spheres.

A new international court that has compulsory jurisdiction in respect of cultural heritage disputes has been a point of discussion. Although many commentators have supported this idea, a new treaty is highly unlikely to be achieved. The implications of jurisdictional rules and challenges in domestic courts retain their relevance and deserve to be kept in view. Chapter 4 elaborates on these themes. Research on culturally sensitive principles has also moved beyond the question of the appropriate mechanism of dispute resolution.

\subsection{Culturally Sensitive Principles to be Considered by Courts, International Tribunals and Arbitral Venues}

Approaches that restrain the uncritical application of ordinary business norms to transactions involving cultural objects have been identified. In an effort to offer a path through the dense and complex terrain of an unstructured international legal order, these approaches have been integrated into a set of culturally sensitive principles deriving from common rules of adjudication. ${ }^{260}$ The application of these common rules and their dissemination is expected to yield a composite body of law - the lex culturalis - that will enhance the protection of cultural heritage. Since it is the intention of a lex culturalis to help prevent the uncritical application of ordinary business norms to transactions involving cultural objects, it draws on dispute resolution mechanisms and substantive uniform law. The willingness to keep in view developments at the cross-over of private international law and ADR qualifies as a strength of the lex culturalis.

The lex culturalis is supposed to be able to reconcile 'all moral, historical, cultural, financial and legal interests'. ${ }^{261}$ In this regard, it is important to keep inflated expectations in check. An integrated body of cultural law, predicated on uniform law that obliges purchasers to seek

Cultural Property Disputes (The Hague 2004) 291; E Varner, 'Arbitrating Cultural Property Disputes' (2012) 14 Cardozo Journal of Conflict Resolution 477.

260 Chechi (n 26) 202, 317-18.

261 Chechi (n 26) 204. 
export documents and ensure a clean chain of title, may be as unattainable as world peace. A global regulatory regime that is premised on a uniform and integrated world law has not been achieved. Not even the simple proposition contained in the erstwhile Draft Convention Providing All Uniform Law on the Acquisition in Good Faith of Corporeal Movables, that ' $[\mathrm{t}]$ he transferee of stolen movables cannot invoke his good faith', made it to convention-status. ${ }^{262}$ An overarching special private international law regime for portable cultural objects remains out of reach also. Modern attempts to avoid the very broad lex situs rule and its connecting factor are partly motivated by the perceived need for non-application of 'cumbersome' private international law rules in claims involving art and cultural objects. However, while it is easy to agree with the non-application of the lex situs rule, it is unrealistic to envisage a body of principles that can reconcile 'all moral, historical, cultural, financial and legal interests'. ${ }^{263}$

Differences in the civil justice systems of states may have an even greater impact than any choice of law rule on the success of claims based on foreign law. The intersection between private international law, ADR, arbitration and culturally sensitive principles by which disputes deserve to be settled invites dedicated development. This work will be facilitated if the yardsticks for measuring impact and success can be agreed. Arguably, as stated earlier, it would be important to promote impeccable, clear acquisition standards; encourage regulatory frameworks that control the spill-over effects of the market onto source states; and foster a deeper commitment to value-based rationality.

Value-based action is evident also from voluntary return. In respect of indigenous cultural heritage, this may be the only option available 264 by which the profound disempowerment of communities who are alienated from their own culture can be overcome.

\section{SCOPE}

The scope of this book is narrowly focused on claims for return arising from the unlawful removal and theft of material, portable culture. This delineation follows that of the first report by the Cultural Heritage Law

262 Art 11 of the Draft Convention Providing All Uniform Law on the Acquisition in Good Faith of Corporeal Movables, reprinted in 1975 (1) Uniform Law Review 66.

263 Chechi (n 26) 204.

264 Graber et al. (n 73) 493. 
Committee of the International Law Association in 2000, which limits the understanding of cultural heritage to tangible goods. The examples used derive from the accumulated material heritage of humankind: e.g. fine art, archaeological materials, indigenous artwork, sacral objects or human remains, art and cultural objects that were stolen, looted, misappropriated or confiscated during armed conflict or in peace time. Restitution, the obstacles to restitution and refusals to make restitution are highlighted in order to illustrate the relationship between arguments in support of restitution and those of private international law.

The analysis covers claims to title or to transfer of title in respect of art and cultural objects that have incomplete or indeterminable provenance, but ostensibly excludes analysis of crimes such as art fraud, forgery, unauthorised commercial reproduction, false attribution, vandalism and iconoclasm. Also excluded are disputes over donations, matters of insurance and indemnity, restoration or confidentiality clauses, and artist representation, copyright and moral rights, reproduction or access rights. ${ }^{265}$

This study is confined to proprietary issues linked to the unlawful removal, theft and restitution of portable material. The competence of a court other than the one that has jurisdiction over the merits of the claim to grant provisional and protective measures to safeguard the object and the rights of the claimant is regulated in secondary law at EU level. The relevant provision has not played a significant role in the management of cross-border litigation, ${ }^{266}$ and therefore this aspect has not been covered. Much more significant is the sharp increase in litigated cases that concern the tension between the right of the lender and the borrower to immunity from seizure in the transnational exchange of art, and the need of the borrowing state, where the art is located, to give effect to its own mandatory civil and criminal law provisions. ${ }^{267}$ However, the contractual dimension is not highlighted as a separate category that determines the

265 E.g. JB Prowda, Visual Arts and the Law (Lund Humphries 2013).

266 Art 31 of Council Regulation (EC) No 44/2001 of 22 December 2000 OJ L 12/1 16.1.2001 (the Judgments Regulation).

267 The implementation of the European Agenda for Culture, the Council Work Plan for Culture 2011-2014 highlighted the importance of intercultural dialogue, and established a priority area on 'Cultural heritage, including mobility of collections' (OJ C 325, 2.12.2010, 1). Meetings held within the framework of the Open Method of Coordination resulted in a Report on Improving the Means of Increasing the Mobility of Collections (OMC Expert Working Group on the Mobility of Collections, Final Report and Recommendations to the Cultural Affairs Committee on Improving the Means of Increasing the Mobility of Collections (June 2010) 7-8, available at http://www.lending-for-europe.eu/ 
applicable law for purposes of this book. The theory and practice of anti-seisure and anti-suit in the context of art loans are outside the scope of this work.

This book is not concerned with voluntary transfers of ownership where the right in rem is attributed in a contract. 268 In fact, the law applicable to contractual obligations is relevant only ${ }^{269}$ in so far as the choice of law remit of arbitrators is concerned. Their remit necessitates reference to the private international law rules governing contracts in the Rome I Regulation on the law applicable to contractual obligations. ${ }^{270}$ The conflict's rules for non-contractual obligations in the Rome II Regulation on the law applicable to non-contractual obligations ${ }^{271}$ would be relevant in respect of a claim for damages in respect of a moveable object. ${ }^{272}$ Property choice of law rules will determine whether a claimant has sufficient title to sue in conversion, but for EU member states the Rome II Regulation may apply to the wrongdoing itself. ${ }^{273}$ These EU choice of law rules, and their effects on the legislation of the Member States and the systems that used to be in place in those Member States, ${ }^{274}$ are not directly relevant for ownership and restitution claims, and fall outside the scope of this work.

The outcome of litigation depends on constellations of facts that may relate to the illicit excavation of previously undiscovered archaeological items; newly discovered cultural material regardless of whether it forms part of the cultural heritage of indigenous peoples; the quality of justice delivered during dispute settlement in claims involving Nazi spoliated art;

fileadmin/CM/internal/OMC/OMC_Mobility_of_Collections_Report_Rome_7_ July10.pdf).

268 As in Italian law for example. See Law no 218 of 1995 Riforma del sistema italiano di diritto internazionale privato.

269 Gazzini (n 75) 63.

270 Regulation (EC) No 593/2008 of the European Parliament and of the Council of 17 June 2008 on the law applicable to contractual obligations (Rome I) OJ L 177, 04.07.2008, 6.

271 Regulation (EC) No 864/2007 of the European Parliament and of the Council of 11 July 2007 on the law applicable to non-contractual obligations (Rome II) OJ L 199, 31.07.2007, 40.

272 The jurisdictional ground which the Recast Regulation now provides for is discussed in detail in Chapter 4.

273 Ulph and Smith (n 81) 249-50.

274 E.g. TD Czigler and I Takacs, 'The Law Applicable to Contracts in the European Union' (2012) 20 The California International Law Journal 21. 
their connection to the passage of time'275 and the "Vergangenheitsbewältigung'. This work does not explore the existence of a right to the protection of cultural property, or map the search for independent, supplementary or alternative paths to obtaining restitution in these cases. $^{276}$ Its focus is confined to claims to tangible cultural heritage, on the understanding that it is a violation of property rights that can come within the protection of the ECHR if such a community is deprived of an object that formed part of its ancestral, cultural and religious environment and gave tribal life meaning, after the Convention took effect. ${ }^{277}$ Western jurisprudence and common law concepts fail to define the right that has been infringed in these circumstances. Considered with reference to the individual right to 'the peaceful enjoyment of [his] possessions' when the individual right of private property and the public interest in the conservation of cultural objects need to be accommodated, ${ }^{278}$ cultural objects are to be protected like any other moveable object. The claims brought by indigenous peoples may be in respect of human remains. ${ }^{279}$ Human remains represent the only category of indigenous cultural property considered in legislation in the UK and the US. ${ }^{280}$ Nonetheless, neither one of these legal systems contains all-encompassing solutions which a UN Declaration may envisage in this category. ${ }^{281}$

275 Veraart and Winkel (n 238) 7.

276 Gazzini (n 75) 48; Kuprecht and Siehr (n 70) 247-48.

277 T O'Donnell, 'The Restitution of Holocaust Looted Art and Transitional Justice: The Perfect Storm or the Raft of Medusa?' (2011) 22 Eur J Int Law 49, 69.

278 Art I of the First Protocol to the European Convention for the Protection of Human Rights and Fundamental Freedoms.

279 K Kuprecht, 'Human Rights Aspects of Indigenous Cultural Property Repatriation' in K Odendahl and PJ Weber (eds), Kulturgüterschutz - Kunstrecht - Kulturrecht: Festschrift für Kurt Siehr (Baden-Baden 2010) 191, 192.

280 The Human Tissue Act (UK) of 2004 regulates the storage, use and disposal of human bodies, organs and tissue and provides for the transfer of human remains from certain museum collections. The Human Tissue (Scotland) Act of 2006 deals with the donation of human tissue and its removal, retention and use following a post-mortem examination. The NAGPRA addresses repatriation of human remains and ownership of sacred objects and objects of cultural patrimony.

281 Art 12 of the UN Declaration on the Rights of Indigenous Peoples, Resolution adopted at the 107th plenary meeting of the General Assembly, 13 September 2007, <http://www.un.org/esa/socdev/unpfii/documents/DRIPS_en. pdf>. 
Development projects that threaten the built heritage ${ }^{282}$ and the position in respect of the underwater heritage ${ }^{283}$ have been covered in dedicated strands of the literature, and will not be analysed here.

\section{METHOD}

This work strives for increased international understanding, realism and putting comparative law and experience to proper use; the very same elements that Rabel identified in order to 'internationalize' private international law. ${ }^{284}$ As long as private international law is treated as a series of separate national rules that draw on national sources, 285 it will be unable to support the orderly coexistence of distinct domestic legal systems. ${ }^{286}$ It is not called on to 'ordinate' national legal systems, but to co-ordinate them - a more specialised function than merely to "put into order'. Co-ordination is about the consistency of private international law as a whole. For present purposes, therefore, it is treated as an 'internationalised' discipline or international system that operates by national courts through national law. The method employed here is congruent with the aim of the work: to demonstrate how private international law can be applied as a global lens in order to achieve a worldwide perspective. The method requires keeping track of its interaction with public international law, international arbitration and dispute settlement,

282 E.g. T Scovazzi, B Ubertazzi and L Zagato (eds), Il Patrimonio Culturale Intangibile nelle sue Diverse Dimensioni (Guiffre 2012); S Theurich, 'Alternative Dispute Resolution in Art and Cultural Heritage - Explored in the Context of the World Intellectual Property Organization's Work' in K Odendahl and PJ Weber (eds), Kulturgüterschutz - Kunstrecht - Kulturrecht: Festschrift für Kurt Siehr (Baden-Baden 2010) 569, 573; MF Brown, 'Heritage Trouble: Recent Work on the Protection of the Intangible Cultural Property' (2005) 12 IJCP 40.

283 Respectively Chechi (n 26) and C Forrest and P Fletcher-Tomenius, 'The Protection of the Underwater Cultural Heritage and the Challenge to UNCLOS' (2000) 5 Art Antiquity and Law 125.

284 E Rabel, The Conflict of Laws: A Comparative Study Vol. 4 (Ann Arbor, U Mich 1958) $97 \mathrm{ff}$.

285 Mills (n 138) 3, 12.

286 C Roodt, 'Reflections on Theory, Doctrine and Method in Choice of Law' (2007) XL CILSA 76, 95, 101. 
and cultural heritage law, and to articulate its relationship with ethics, ADR, soft law and EU law. ${ }^{287}$

Realism is a vital ingredient of this study. In the context of art crime, the analysis is informed by quantitative studies that correlate lootings with the appearance of categories of objects on the market. ${ }^{288}$ The analysis of the theory and method of private international law seeks to highlight the risks of dogmatic compartmentalisation and methodological fundamentalism that is bent on finding a single workable conflicts method or category or connecting factor. Such conceptual splits can only lead to unpalatable outcomes.

International civil procedure and choice of law methodology have always been heavily reliant upon the trends that are notable across jurisdictions. Not only does information on the content of potentially applicable foreign legal systems assist in conflict situations and classification conflicts, but a functional approach to comparative law helps identify best practice on the basis of a comparative ethos. ${ }^{289}$ This is a vital aspect in the pursuit of law that serves the aims of global welfare. Comparative law and private international law share the same origin: global legal pluralism. ${ }^{290}$ Comparative law and experience should keep the researcher alive to the convergence of legal traditions on the acquisition of works of art. ${ }^{291}$ Nonetheless, harmonised substantive law or centralised institutions are but one way of coping with legal diversity. Even if the great majority of states were to agree on common principles of substantive law, this would not automatically imply mutual recognition of their national regimes of cultural property protection. ${ }^{292}$ Cultural heritage law has been left untouched by the progressive unification of private international law rules, which is foremost among the aims of the Hague Conference on private international law. ${ }^{293}$ In any event, even if this area of law were harmonised, unification is a project that will never

287 DPF Arroyo, 'Private International Law and Comparative Law: A Relationship Challenged by International and Supranational Law' (2009) XI Yearbook of Private International Law 31, 62, 71.

288 Gerstenblith (n 107) 207-9 discusses several empirical studies.

289 E.g. Prott's comparative analysis of the major obstacles to successful restitution claims in national courts. Prott (n 26) 214.

290 Fauvarque-Cosson (n 212) 409.

291 Schönenberger (n 43) 252-53.

292 Siehr (n 179) 25.

293 Established as an inter-governmental organisation in 1955, with traditions dating back to 1893. Statute of the Hague Conference on Private International Law, 15 July 1955, UNTS 220 (123). 
be completed. ${ }^{294}$ Divergent judicial interpretations will always create new conflicts. The legal diversity that underlies many restitution claims can render justice pluralism inevitable. A decision can be based on strict law, ethics or on the facts of the case. ${ }^{295}$ The principle of justice pluralism is revisited again in Chapter 6, where it is argued that acceptance of this principle turns access to justice into the overriding concern. Once access to justice is certain, adjudicators need to identify, and make the most of opportunities to make value-based decisions that limit the scope for criminal activity and maximise the protection of the object.

Fundamental rights norms and communautarisation shape and change both disciplines. Where the ECHR applies, the use of the public policy exception intensifies, necessitating even more extensive recourse to comparative method. ${ }^{296}$ It has been argued that communautarisation in the context of the EU renders the differences and antagonisms between the methods, aspirations and respective dynamisms of these two disciplines more visible. ${ }^{297}$ However, communautarisation can also be viewed as a factor that prompts private international law to make an outward turn. This aspect is revisited in Chapter 3.

\section{OUTLINE}

Chapter 1 introduces the role private international law can play in the protection of art and cultural objects. Among other things, these objects can be conceived of as part of national identity; as moveable artefacts susceptible to economic evaluation; as expressions of human creativity that possess intrinsic value; as objects of human rights in peacetime; ${ }^{298}$ or as objects that claim special protection in the international law of armed conflict. ${ }^{299}$ The nature, definition and status of these objects pose challenges in disputes that arise from international art sales. Post-theft,

\footnotetext{
294 Fauvarque-Cosson (n 212) 414.

295 Mills (n 138) 6.

296 Fauvarque-Cosson (n 212) 409-10.

297 J Kropholler, 'Die Vergleichende Methode und das Internationale Privatrecht' (1978) 77 Zeitschrift für Vergleichende Rechtswissenschaft 1; M Reimann, 'Comparative Law and Private International Law' in M Reimann/R Zimmermann (eds), The Oxford Handbook of Comparative Law (Oxford 2006) 1363, 1366; B Grossfeld, The Strength and Weakness of Comparative Law (Oxford 1990) 19. 298 FN Brodie, J Doole and P Watson, Stealing History: The Illicit Trade in Cultural Material (MacDonald Institute for Archaeological Research 2000) 11.

299 F Francioni, 'The Human Dimension of International Cultural Heritage Law: An Introduction’ (2011) 22 EJIL 9, 9-10.
} 
post-excavation or post-confiscation transactions on the art market frequently cross borders. Private international law can constrain the commercial imperative when the trade falls short of acquisition and collection standards. It can also offer support to cultural heritage law in restitution claims if the synergies that can arise between trafficking and the substance of the law applied in the jurisdictions that are used for laundering purposes can be anticipated. Commercial interaction on the art market, and the way in which traffickers and dealers position themselves in relation to the law, invite private international law to help identify appropriate forms of justice. The broader context within which private international law operates is informed by ethics and by dispute resolution processes. The scope and the method used in the book reflect these broad perspectives.

The pressure of global legal diversity demands solutions that are attuned to the international dimension of art and heritage claims that are based on ownership or possession of a thing. Chapter 2 considers the grounds, limits and international dimension of restitution. The categories of restitution claims are discussed and circumstances in which restitution would be inappropriate indicated. The perplexing problems introduced by private international law in claims for restitution are highlighted, together with the opportunities and the potential this discipline presents to facilitate restitution and dispute settlement by fulfilling its specialised co-ordination function.

Chapter 3 explores the turn(s) which private international law must make for its structure and method to respond appropriately to developments in cultural heritage law. Complex choices available in international cases must be simplified and drawn together with the help of a global lens that brings into better view customary international law, international conventions states enter into to prevent the transfer of stolen cultural objects, soft law, EU law and the ECHR.

That systems of civil justice differ is an important aspect of legal diversity and the obstacles it presents in claims for restitution brought by states, private actors, museums or groups. Jurisdictional rules and challenges control the venue in which a case proceeds. Litigation about where to litigate a claim involving a work of art or a cultural object carries a risk that the merits of the case may not be ventilated. Chapter 4 considers jurisdictional rules relied upon under the UNIDROIT Convention, in the EU, and in US courts. One of the challenges is to keep the consistency of private international law in mind. The chapter highlights the implications of forum-shopping and of the need for consistency of decision across international cases. The defendant may prefer artificial procedural arguments that steer the court away from value-based 
decision-making. Parties have scope to choose where to take their dispute, and the defendant may indicate that another court is more appropriate to exercise jurisdiction. The question of arbitration as a dispute resolution mechanism in cultural property disputes is investigated, and mechanisms that prevent the re-litigation of cases and wasting of judicial resources are considered. The main argument is that these mechanisms need to be used in ways that foster access to justice in claims for restitution.

Chapter 5 deals with the potential to use the structure and method of private international law to deter title laundering. Consigners of stolen or smuggled works of art and cultural objects are tempted to hide behind the good-faith purchase laws of certain European countries such as Italy and France and to argue that title was validly transferred. It is widely conceded that cultural objects deserve special treatment, and yet in practice general commercial law rules are given extended application and little or no due diligence is required. Courts have used the property transaction as a basis for classification when art was retained by a third party purchaser after having crossed jurisdictional lines post-theft. The effect of the passage of time on the claim will be referred to the same law if classified as a matter of substantive law. Choice of law method can be used to mark the fact of theft or the context of smuggling instead of fortifying the interests of the market and neglecting those of the cultural community in question. The structure and method of private international law enables jurisdictions to block transfer of defective title, to compensate for the oversimplification of the problems that arise in art transactions on account of the lex situs rule, and to ease tensions between private law and criminal law in the art markets in New York and London. Legal developments in the UK and specifically New York acknowledge the inherent taint or defect in a title to property which attaches to stolen goods until they are returned to the original owner. These developments demonstrate how private international law can support the objective of restitution embodied in pertinent international instruments.

Chapter 6 considers claims for restitution and the procedure-based argument for non-restitution of dispossessed Nazi spoliated art. Claimants may engage in jurisdictional trade when immunity legislation does not prevent this. The success of mediated claims to Nazi spoliated art in a number of European jurisdictions contrasts sharply with the low recovery rate through litigation in the US. When it comes to determining the venue for dispute resolution of Nazi-looted art cases, process and substance tend to interlink remarkably closely. Domestic and applicable law arguments provide scope for non-restitution in the context of the definition of a 'forced sale' and the lex situs rule. Procedural advantages 
in court may preclude a hearing on the substantive merits of the case. While courts may be a popular choice for this reason, this preference may also rule out value-based decisions that can take proper account of ethical considerations. Mediation committees in France, Germany, the Netherlands and the UK give advice that is value-based. Except for the Spoliation Advisory Panel in the UK, these committees do not draw a distinction between recommendations affecting public or private ownership. National developments in respect of restitution do not occur in isolation. The principle of international law that spoils of war can be claimed back by their country of origin if identified and found has long existed. Various peace treaties concluded from the seventeenth century onwards embody the idea of return or compensation. ${ }^{300}$ This principle continues to affect global restitution practices, which indicate differences not only in respect of the treatment accorded to objects won in economic or colonial conquests and objects looted in armed conflicts, but also in respect just of the last-mentioned category. Practice has also been affected by policy changes and renewed interest in restitution to victims of the Holocaust since 1989. The chapter considers the reasons for these policy changes in greater detail.

Chapter 7 explores the application of foreign public law in sovereign claims that are accessory to private law in US, UK and German law. Ultimately, it is vital to cultivate international understanding and to foster mutual assistance in situations where foreign prevention and control measures and criminal sanctions cannot be applied directly to protect significant items of cultural heritage. International policy ought to be based on the need for mutual assistance when it comes to safeguarding against physical damage, dismemberment and decontextualisation, as much as against depriving states of the opportunity to do so. Civil forfeiture could be based on a violation of a criminal statute ${ }^{301}$ and could provide a basis for the enforcement of accessory claims to trafficked cultural objects that are based on foreign public law. ${ }^{302}$ A claim may also be based on private law. ${ }^{303}$ Account may be taken of foreign public law by means of the recognition of the category of property that applies in the state in which the theft occurred and by whose law restitution would

\footnotetext{
300 Gazzini (n 75) 5.

301 United States v Hollinshead, 495 F2d 1154 (9th Circuit 1974); US v McClain, 545 F2d 658 (1978), US v McClain, 593 F2d 658 (1979), cert denied, 444 US 918 (1979) 671.

302 Per Staughton J in Attorney-General of New Zealand v Ortiz [1982] 3 All ER 432 at 451.

303 Jakubowski (n 76) 139.
} 
be justified, or by way of novel ways of applying domestic law. Regardless of the legal basis of the claim, judicial consideration of the legal nature of state claims for the return of illicitly trafficked cultural objects is called for. The recognition by domestic courts of a public law category is a controversial issue in private international law. ${ }^{304}$ Courts readily enforce the contract and delict claims brought by private parties, but they may be more hesitant to enforce foreign public law. ${ }^{305}$ Valuebased decisions depend on recognizing the capacity of private international law to relax the strict public policy objection to such a claim.

304 Jakubowski (n 76) 140; AF Lowenfeld, 'Public Law and the International Arena: Conflict of Laws, International Law, and Some Suggestions for their Interaction' II (163) Recueil des Cours (Sijthoff \& Noordhoff 1980) 311.

305 Per Lord Denning MR in Attorney-General of New Zealand v Ortiz. [1982] 3 All ER 456j-457. 